\title{
Identification and Detection of Phytophthora: Reviewing Our Progress, Identifying Our Needs
}

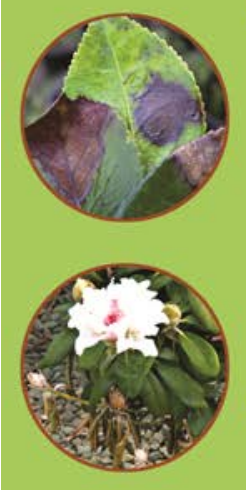

Frank N. Martin

USDA, ARS, Crop Improvement and Protection Research Unit, Salinas, CA

Z. Gloria Abad

USDA, APHIS, PPQ, Center for Plant Health Science and Technology (CPHST), Beltsville Laboratory, MD

Yilmaz Balci

Department of Plant Sciences and Landscape Architecture, University of Maryland, College Park, MD

Kelly Ivors

Department of Plant Pathology, NC State University, Mountain Hort. Crops Research \& Extension Center, Mills River, NC

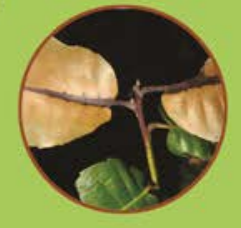

With the increased attention given to the genus Phytophthora in the last decade in response to the ecological and economic impact of several invasive species (such as $P$. ramorum, $P$. kernoviae, and $P$. alni), there has been a significant increase in the number of described species. In part, this is due to the extensive surveys in historically underexplored ecosystems (e.g., forest and stream ecosystems) undertaken to determine the spread of invasive species and the involvement of Phytophthora species in forest decline worldwide (e.g., oak decline). Brasier (41) cited the number of described species in 1999 at approximately 55, and there has been an increase of an additional 50 species or distinct taxonomic entities described between 2000 and 2007. This represents a near doubling in eight years! Érsek and Ribeiro (80) recently updated the list of described species to 100; since then, additional species have been named (some provisional), raising the total to 117 (Table 1) with a number of other distinct taxonomic entities in the process of formal description. The number of species will likely continue to increase as more surveys are completed and greater attention is devoted to clarifying phylogenetic relationships and delineating boundaries in species complexes. The development of molecular resources, including the recent comprehensive multigene phylogenetic analysis of the genus (32), the availability of credible sequence databases to simplify identification of new species (www.phytophthoradb.org, www.phytophthora-id.org, www.qbank.eu, and www.boldsystems.org), and the sequencing of several genomes $(107,278)$ have provided a solid framework to move forward. Gaining a better understanding of the biology, diversity, and taxonomic relationships within the genus will be important for the improvement of identification and diagnostic protocols. This information is much needed considering the impact invasive or exotic Phytophthora species have had on natural ecosystems and the regulatory issues associated with their management. Reviews by Cooke et al. (61) and O'Brien et al. (217) are noteworthy for providing additional information on molecular identification and detection.

Corresponding author: Frank N. Martin, USDA, ARS, Crop Improvement and Protection Research Unit, Salinas, CA;

E-mail: Frank.Martin@ars.usda.gov.

Table 1 is also available, in a slightly different format, online.

http://dx.doi.org/10.1094/PDIS-12-11-1036-FE

This article is in the public domain and not copyrightable. It may be freely reprinted with customary crediting of the source. The American Phytopathological Society, 2012.

\section{Taxonomy of the Genus Phytophthora}

Numerous studies on the taxonomy of Phytophthora have been published since the initial description of the type species of the genus, Phytophthora infestans (Mont.) de Bary, in 1876 (reviewed in Erwin and Ribeiro, 82). Most of the publications contain dichotomous keys for species identification with the exception of Stamps et al. (253), which includes a tabular format based on keys developed by Waterhouse $(286,287)$. Waterhouse (286) introduced the concept of morphological groupings (I-VI) "with the intent to solely serve as an aid to species identification, and not meant to imply a natural classification”. Newhook et al. (213) and Stamps et al. (253) also included these groupings in their taxonomic evaluation of the genus. More recent attempts to simplify identification of species include a manual for identification of 60 species of Phytophthora by integration of a dichotomous key with a DNA fingerprinting technique based on polymerase chain reaction (PCR)single strand conformational polymorphism (SSCP) (88) and a Lucid Key for identification of 55 common Phytophthora spp. based on a series of interactive computer matrices (230). Cline et al. (55) have published an online list of Phytophthora spp. occurring in the United States as well as species occurring elsewhere with a hyperlink for each species to the USDA SMML database that includes host range, distribution, and supporting literature. Recently, Kroon et al. (166) provided an update on the taxonomy of the genus.

\section{Phylogeny of the Genus Phytophthora}

Historically, the genus Phytophthora has been placed in the Pythiales with Pythium and related genera, but more recent phylogenetic analysis with the large (LSU) or small (SSU) ribosomal DNA (rDNA) sequences or cox 2 gene has indicated a closer affiliation with downy mildews and white rusts (Albugo spp.) in the Peronosporales $(21,261)$. However, additional multigene analysis with a larger number of downy mildew species is needed to better characterize this relationship and the placement of Phytophthora spp. in clades 9 and 10 (32). The relationship between the Peronosporales and Pythium (Pythiales) needs clarification as well. Recently, a new genus, Phytopythium, was erected to accommodate an inconsistency between taxonomic and phylogenetic grouping for these two genera (17), and it is likely that additional taxonomic revisions of the Peronosporomycetidae with additional genera added to the analysis will be needed to fully resolve other taxonomic conflicts.

A comprehensive multilocus phylogenetic analysis of 82 species in the genus was recently completed by Blair et al. (32), and for the most part the phylogenetic groupings were similar to those ob- 
served in the internal transcribed spacer (ITS) analysis by Cooke et al. (58) and the multilocus analysis of Kroon et al. (165). While Cooke et al. (58) reported 8 major clades, with the addition of more recently described species Blair et al. (32) observed 2 additional groupings (clades 9 and 10) that were basal to the prior 8 clades. The same isolates used in Blair et al. (32), along with more recently described species, were also used in a current mitochondrial multilocus analysis, and with a few exceptions, results were similar (Fig. 1). While phylogenetic groupings have exhibited some similarity with the morphological groupings of Waterhouse (286) and placement of species on individual clades, this was not an absolute correlation, and a number of exceptions were observed. There was no consistent correlation between reproductive strategy (homothallic versus heterothallic) or antheridial attachment (paragynous versus amphigynous) with phylogenetic grouping. A variety of other nuclear and mitochondrial loci (discussed below) have been used in phylogenetic analysis of the genus $(165,195$, 196,283; see also www.phytophthoradb.org).

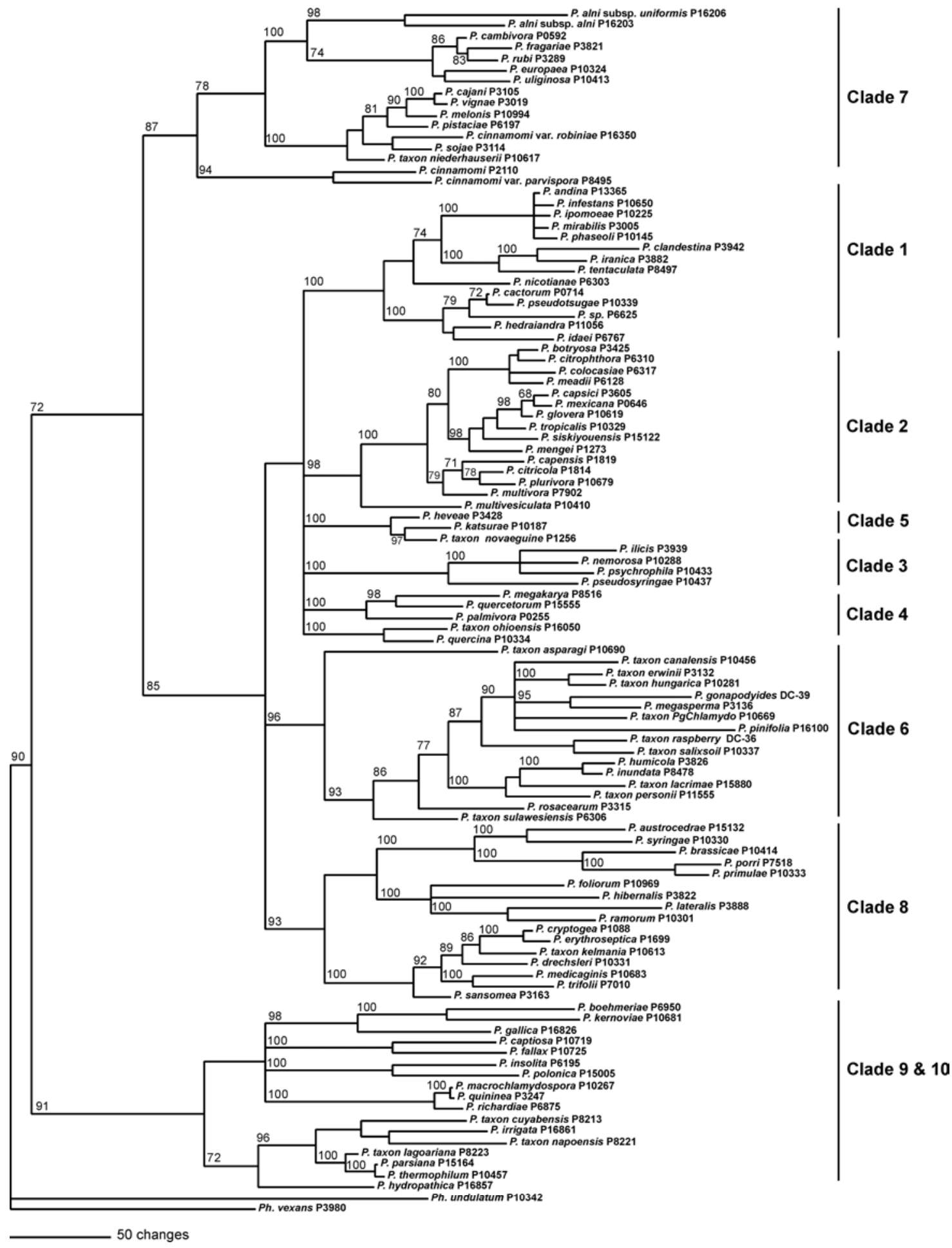

Fig. 1. Maximum parsimony analysis of concatenated cox2, nad9, rps10, and secY genes from a range of Phytophthora spp. with Phytopythium vexans and Ph. undulatum as outgroups (F. Martin, J. Blair, and M. Coffey, unpublished). The numbers at the nodes represent bootstrap values (below $70 \%$ is not presented) with the clade labeling the same as Blair et al. (32). 
Table 1. List of described Phytophthora species and their asexual and sexual morphological features, temperature growth range, Waterhouse morphological grouping, and placement in phylogenetic analysis

\begin{tabular}{|c|c|c|c|c|c|c|c|c|c|c|c|c|c|c|c|}
\hline \multirow[b]{2}{*}{ Species } & \multicolumn{7}{|c|}{ Asexual phase } & \multicolumn{4}{|c|}{ Sexual phase } & \multicolumn{2}{|c|}{ Temperature } & \multirow[b]{2}{*}{ WGn } & \multirow[b]{2}{*}{ Clade $^{\circ}$} \\
\hline & $\mathrm{PA}^{\mathrm{a}}$ & $\mathrm{Cb}^{\mathrm{b}}$ & PEc & $P^{d}$ & SPO & $\mathrm{CH}^{\mathrm{f}}$ & HSg & $\mathrm{H}^{\mathrm{h}}$ & OOGi & $\mathrm{ANj}$ & oosk & OPM' & MAXm & & \\
\hline P. cactorum & $\mathrm{P}$ & $c$ & $\mathrm{~s}$ & - & CLS & $\mathrm{CH} /-$ & - & но & $\mathrm{s}$ & $P$ & P/A & $21-27$ & $<30 \mathrm{C}$ & 1 & 1a \\
\hline P. hedraiandra & $\mathrm{P}$ & c & $s$ & . & SSIUN & . & HSI- & Hо & $s$ & P/A & SA & $24-27$ & $<30 \mathrm{C}$ & 1 & $1 \mathrm{a}$ \\
\hline P. idaeip & $\mathrm{P}$ & . & . & . & ss & . & - & Hо & $s$ & $P / A$ & $A$ & $18-24$ & $<27 \mathrm{C}$ & 1 & $1 \mathrm{a}$ \\
\hline P. pseudotsugae & $\mathrm{P}$ & . & . & . & ss & . & HS & но & $s$ & P/A & PIA & 18-24 & $<27 \mathrm{C}$ & 1 & 1a \\
\hline P. clandestina ${ }^{p}$ & $\mathrm{P}$ & $\mathrm{Cl}-$ & $s$ & . & UN & . & HS & но & $s$ & P/A & P/A & $18-22$ & $<28 \mathrm{C}$ & 1 & $1 \mathrm{~b}$ \\
\hline P. iranica & $\mathrm{P}$ & . & . & . & cs & . & HS & Hо & $s$ & P/A & A & $24-30$ & $<33 \mathrm{C}$ & 1 & $1 \mathrm{~b}$ \\
\hline P. tentaculatap & $\mathbf{P}$ & $c$ & s & - & UN/SS & $\mathrm{CH}$ & HS & но & s & PIA & PIA & $21-24$ & $<30 \mathrm{C}$ & 1 & $1 \mathrm{~b}$ \\
\hline P. nicotianae & $\mathrm{P}$ & Cl- & s & . & ss & $\mathrm{CH}$ & HS & HT & $s$ & A & P/A & $24-33$ & $>35 \mathrm{C}$ & ॥ & 1 \\
\hline P. andina & $S P$ & $\mathrm{C}$ & $s$ & . & cs & - & . & HT & $s$ & $\mathrm{~A}$ & P/A & $20-24$ & $<30 \mathrm{C}$ & IV & $1 c$ \\
\hline P. infestans & $S P$ & $c$ & $\mathrm{~s}$ & . & cs & . & . & HT & $\mathrm{s}$ & A & P/A & $18-20$ & $<24 \mathrm{C}$ & IV & $1 \mathrm{c}$ \\
\hline P. ipomoea & $S P$ & $c$ & $s$ & . & cs & . & . & но & $s$ & A & P/A & $18-24$ & $<24 C$ & III & $1 c$ \\
\hline P. mirabilis & $\mathrm{SP}$ & $c$ & $s$ & . & cs & . & . & HT & $s$ & $\mathrm{~A}$ & PIA & $18-20$ & $<24 \mathrm{C}$ & IV & $1 c$ \\
\hline P. phaseoli & $S P$ & $\mathrm{c}$ & $\mathrm{S} / \mathrm{M}$ & . & ss & . & . & но & $s$ & A & A & $18-24$ & $<27 \mathrm{C}$ & III & $1 \mathrm{c}$ \\
\hline P. botryosa ${ }^{p}$ & $\mathrm{P}$ & $\mathrm{C}$ & M & - & ss & $\mathrm{CH} /-$ & . & HT & s & A & $\mathrm{P}$ & $21-26$ & $<32 \mathrm{C}$ & $॥$ & $2 a$ \\
\hline P. himansilva & $P$ & $\mathrm{Cl}-$ & M & - & SSIUN & - & - & HO & s & $\mathrm{P} / \mathrm{A}$ & $A$ & $20-25$ & $<30 \mathrm{C}$ & $\Perp$ & $2 a$ \\
\hline P. meadiip & PISP & $c$ & M & . & SSIUN & $\mathrm{CH} /-$ & . & $\mathrm{HT} / \mathrm{HO}$ & $s$ & A & SA & $25-30$ & $<33 C$ & ॥ & $2 a$ \\
\hline P. citrophthora & $\mathrm{SP}$ & - & - & . & IB & $\mathrm{CH} /-$ & . & HT & $s$ & A & $\mathrm{P}$ & $24-30$ & $<33 C$ & IV & $2 a$ \\
\hline P. colocasiae & $S P$ & $c$ & M & . & IB & $\mathrm{CH}$ & HS & HT & $s$ & A & A & $21-27$ & $<33 \mathrm{C}$ & IV & $2 a$ \\
\hline P. inflata & $\mathrm{SP}$ & - & - & . & UN & - & HSI- & но & $\mathrm{s}$ & $P$ & $\mathrm{P}$ & $25-30$ & $<35 \mathrm{C}$ & III & $2 a$ \\
\hline P. capsici & $\mathrm{P}$ & c & $\mathrm{L}$ & . & ss & - & HS & HT & $s$ & A & $\mathrm{P}$ & $27-33$ & $>35 \mathrm{C}$ & $\|$ & $2 \mathrm{~b}$ \\
\hline P. glovera & $P$ & . & - & - & ss & - & - & но & $s$ & PIA & A & $20-25$ & $<30 \mathrm{C}$ & 1 & $2 b$ \\
\hline P. mexicana & $\mathrm{P}$ & . & . & - & UN/SS & $\mathrm{CH}$ & . & HT & $s$ & A & $\mathrm{P}$ & $25-30$ & $<35 \mathrm{C}$ & ॥ & $2 \mathrm{~b}$ \\
\hline P. tropicalis & $\mathrm{P}$ & $c$ & $\mathrm{~L}$ & . & UN/SS/U & $\mathrm{CH}$ & . & HT & $s$ & A & $\mathrm{P}$ & $27-30$ & $<33 C$ & $\|$ & $2 \mathrm{~b}$ \\
\hline P. siskiyouensis & $S P$ & $\mathrm{Cl}-$ & $\mathrm{L}$ & . & UN/SS & - & HS & Hо & S/tb & PIA & P/A & $21-25$ & $<27 \mathrm{C}$ & III & $2 \mathrm{~b}$ \\
\hline P. frigida ${ }^{p}$ & $\mathrm{P}$ & $c$ & $s$ & . & ss & $\mathrm{CH}$ & HS & HT & $s$ & A & $A$ & $20-25$ & $<30 \mathrm{C}$ & ॥ & 2 \\
\hline P. bisheria & $S P$ & . & . & - & UN & - & HS & но & $s$ & $\mathrm{P}$ & $A$ & $18-24$ & $<30 \mathrm{C}$ & III & 2 \\
\hline P. capensis & $S P$ & - & - & . & UN & - & - & Hо & $s$ & $\mathrm{P}$ & $\mathrm{P}$ & $18-24$ & $<28 \mathrm{C}$ & III & 2 \\
\hline P. citricola & SP & . & - & . & ss & . & - & Hо & $s$ & $P$ & $\mathrm{P}$ & $24-30$ & $<31 \mathrm{C}$ & III & 2 \\
\hline P. elongata & $S P$ & . & . & . & UN/SS & . & . & но & S/tb & $\mathrm{P}$ & PIA & $20-25$ & $<30 \mathrm{C}$ & III & 2 \\
\hline P. mengei & SP & - & - & . & SSIUN & - & - & Hо & S/tb & $\mathrm{P}$ & PIA & $20-25$ & $<33 C$ & III & 2 \\
\hline P. multivesiculatap & SPINP & . & - & PR & UN/SS & . & HS & HO & S/tb & $\mathrm{P} / \mathrm{A}$ & $\mathrm{A}$ & $21-27$ & $<35 \mathrm{C}$ & III & 2 \\
\hline P. multivora & SP & . & - & . & SS & . & HS & HO & S/tb & $\mathrm{P}$ & $P$ & $18-30$ & $<30 \mathrm{C}$ & III & 2 \\
\hline
\end{tabular}

(continued on next page)

\footnotetext{
a Sporangia papillae with $\mathrm{P}=$ papillate $(\geq 3.5 \mu \mathrm{m}), \mathrm{SP}=$ semipapillate $(\leq 3.5 \mu \mathrm{m}), \mathrm{NP}=$ nonpapilate.

b Caducity of sporangia with $\mathrm{C}=$ caducous, $\mathrm{Cl}-=$ sometimes caducous, and " - " $=$ not caducous.

c Pedicle length with $\mathrm{S}=$ short $(<5 \mu \mathrm{m}), \mathrm{M}=$ medium $(5-20 \mu \mathrm{m}), \mathrm{L}=$ long $(>20 \mu \mathrm{m})$, and "-" = no pedicle.

d Proliferating sporangia $=$ PR, " $"$ " = nonproliferating.

e Sporangiophore form CLS = Close sympodium, SS = simple sympodial, un = unbranched, CS = compound sympodial, IB = irregularly branched, U = umbellate, D.DM = Downy mildew shape, and ? = no reported.

${ }^{\mathrm{f}}$ Formation of chlamydospores with $\mathrm{CH}=$ formed, $\mathrm{CH} /-$ = sometimes formed, and "-" = not formed.

g Formation of hyphal swellings with HS = formed, HS/- = sometimes formed, and "." = not formed.

${ }^{\text {h }}$ Reproductive strategy with $\mathrm{HO}=$ homothallic and $\mathrm{HT}=$ heterothallic.

i Oogonial wall with $\mathrm{S}=$ smooth, $\mathrm{O}=$ ornamented, $\mathrm{S} / \mathrm{O}=$ smooth and ornamented, $\mathrm{S} / \mathrm{SW}=$ smooth and slight wavy wall, $\mathrm{O} / \mathrm{tb}=$ ornamented wall and tapered base, $\mathrm{S} / \mathrm{tb}=$ smooth wall and tapered base.

j Antheridial attachment with $\mathrm{P}=$ paragynous, $\mathrm{A}=$ amphigynous, and $\mathrm{P} / \mathrm{A}=$ both present.

${ }^{\mathrm{k}}$ Space between oospore and oogonial wall with $\mathrm{P}=$ plerotic, $\mathrm{A}=$ aplerotic, $\mathrm{P} / \mathrm{A}=$ both plerotic and aplerotic, and $\mathrm{SA}=$ slightly aplerotic .

${ }^{1}$ Optimum temperature for growth.

$\mathrm{m}$ Maximum temperature for growth.

${ }^{\mathrm{n}}$ Morphological group of Waterhouse (286).

${ }^{\circ}$ Phylogenetic clade $(32,58)$.

p Species that are on the list "Prioritization of Phytophthora of Concern to the United States" (245).

q ? refers to unknown character, species is sterile or does not produce sexual stage.
} 
Table 1. (continued from previous page)

\begin{tabular}{|c|c|c|c|c|c|c|c|c|c|c|c|c|c|c|c|}
\hline \multirow[b]{2}{*}{ Species } & \multicolumn{7}{|c|}{ Asexual phase } & \multicolumn{4}{|c|}{ Sexual phase } & \multicolumn{2}{|c|}{ Temperature } & \multirow[b]{2}{*}{ WGn } & \multirow[b]{2}{*}{ Clade $^{\circ}$} \\
\hline & $P A^{a}$ & $\mathrm{Cb}^{\mathrm{b}}$ & PEc & $P^{d}$ & SPO & $\mathrm{CH}^{\mathrm{f}}$ & $\mathrm{HSg}$ & $\mathrm{H}^{\mathrm{h}}$ & OOGi & $\mathrm{ANj}$ & Oosk & OPMI & MAXm & & \\
\hline P. pini & SP & - & - & . & ss & - & HSI- & но & s & $P$ & $P$ & $18-27$ & $<31 \mathrm{C}$ & III & 2 \\
\hline P. plurivora & SP & - & - & PR & ss & . & . & но & S/tb & $\mathrm{P}$ & $\mathrm{P}$ & $18-27$ & $<30 \mathrm{C}$ & III & 2 \\
\hline P. ilicis & SP & c & $S / M$ & . & ss & $\mathrm{CH} /-$ & - & но & $s$ & A & $\mathrm{P}$ & $15-18$ & $<24 \mathrm{C}$ & III & 3 \\
\hline P. nemorosa & $S P$ & c & M & . & ss & . & HS & но & $s$ & A & PIA & $15-20$ & $<21 C$ & III & 3 \\
\hline P. pseudosyringae & SP & Cl- & $S / M$ & . & ss & . & HS & Hо & S/tb & PIA & PIA & $21-24$ & $<25$ & III & 3 \\
\hline P. psychrophila & $S P$ & Cl- & M & . & ss & $\mathrm{CH}$ & - & Hо & S/tb & A & PIA & $15-21$ & $<21 C$ & III & 3 \\
\hline P. alticolap & $P$ & $c$ & $s$ & . & SSICS & $\mathrm{CH} /-$ & HS & но & $\mathrm{s}$ & PIA & A & $25-30$ & $<30 \mathrm{C}$ & 1 & 4 \\
\hline P. arenaria & $P$ & - & . & . & UN.gs & - & HS & но & SW/tb & $\mathrm{P}$ & A & $25-30$ & $<32 \mathrm{C}$ & 1 & 4 \\
\hline P. litchii & $\mathrm{P}$ & - & - & PR & D.DM & - & . & но & $\mathrm{s}$ & PIA & PIA & ND & ND & 1 & 4 \\
\hline P. palmivora & $P$ & $c$ & $s$ & . & ss & $\mathrm{CH}$ & HS & HT & $s$ & A & P/SA & $24-30$ & $<33 C$ & ॥ & 4 \\
\hline P. quercetorum & $\mathrm{P}$ & . & . & . & UN/SS & $\mathrm{CH} /-$ & . & но & $S / t b$ & $\mathrm{P}$ & $A$ & $18-24$ & $<30 \mathrm{C}$ & 1 & 4 \\
\hline P. megakaryap & $P$ & $c$ & M & . & ss & $\mathrm{CH} /-$ & . & HT & S/tb & A & PIA & $21-27$ & $<27 \mathrm{C}$ & ॥ & 4 \\
\hline P. quercinap & $\mathrm{P}$ & . & . & . & ss & $\mathrm{CH} /-$ & HS & Hо & S/tb & $\mathrm{P}$ & PIA & $21-24$ & $<25$ & 1 & 4 \\
\hline P. heveae & $\mathrm{P}$ & . & . & . & ss & . & . & Hо & S/tb & $\mathrm{A}$ & $A$ & $21-27$ & $<27 \mathrm{C}$ & 1 & 5 \\
\hline P. katsurae ${ }^{p}$ & $P$ & . & . & . & IB & $\mathrm{CH} /-$ & . & но & 0 & A & SA & $21-27$ & $<32 C$ & 1 & 5 \\
\hline$P$. inundata & $\mathrm{NP}$ & - & - & PR & UN/SS & - & HS & $\mathrm{HT}$ & $s$ & A & P/A & $27-30$ & $>36 \mathrm{C}$ & $\mathrm{VI}$ & 6 \\
\hline P. gemini & $\mathrm{NP}$ & & 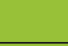 & . & UN & - & HS & $\mathrm{s}$ & - & - & - & $24-27$ & $<33 C$ & VI? & 6 \\
\hline P. humicola & NP & - & - & PR & UN & . & HS & Hо & $s$ & PIA & SA & $27-30$ & $>36 \mathrm{C}$ & v & 6 \\
\hline P. rosacearum & $\mathrm{NP}$ & - & - & - & UN & - & HSI- & но & $s$ & $\mathrm{P}$ & PIA & $27-33$ & $<33 C$ & v & 6 \\
\hline P. pinifoliap & NP & $\mathrm{Cl}-$ & $-/ M$ & . & ss & . & HSI- & $\mathrm{s}$ & - & - & - & $13-18$ & $<20$ & VI? & 6 \\
\hline P. thermophila & $\mathrm{NP}$ & - & - & PR & UN & $\mathrm{CH}$ & HS & S/HO & $\mathrm{s}$ & $P$ & A & $25-32$ & $>35 \mathrm{C}$ & V? & 6 \\
\hline P. litoralis & $\mathrm{NP}$ & - & - & $P R$ & UN & $\mathrm{CH} /-$ & HS & $s$ & - & - & - & $25-30$ & $<32 \mathrm{C}$ & VI? & 6 \\
\hline P. fluvialis & $\mathrm{NP}$ & - & - & PR & UN & . & HS & $s$ & - & - & - & 28-32 & $>35 \mathrm{C}$ & VI? & 6 \\
\hline P. gonapodyides & $\mathrm{NP}$ & - & - & PR & UN & - & HS & $\mathrm{S} / \mathrm{HT}$ & $s$ & A & P/A & $24-27$ & $<30 \mathrm{C}$ & VI? & 6 \\
\hline P. megasperma & NP & - & - & PR & UN/SS & - & HS & но & $s$ & $\mathrm{P}$ & PIA & $18-27$ & $<27 \mathrm{C}$ & v & 6 \\
\hline P. gibbosa & NPISP & - & - & PR & UN & - & $\mathrm{HS} /-$ & Hо & S/SW & A & A & $25-30$ & $<32 \mathrm{C}$ & v & 6 \\
\hline$P$. gregata & NP & - & - & PR & UN & . & HS & но & S/tb & P/A & A & $20-25$ & $<32 \mathrm{C}$ & v & 6 \\
\hline P. alni sub sp. alnip & NP & - & - & PR & UN & - & . & но & O/tb & A & $P$ & $18-24$ & $<29 \mathrm{C}$ & v & $7 a$ \\
\hline P. alni sub sp. multiformis ${ }^{p}$ & NP & - & - & PR & UN & - & . & но & O/S & $\mathrm{P} / \mathrm{A}$ & $\mathrm{P}$ & $21-24$ & $<30 \mathrm{C}$ & v & $7 a$ \\
\hline P. alni sub sp. uniformis ${ }^{p}$ & NP & - & - & $P R$ & UN & - & . & Hо & $\mathrm{s} / 0$ & A & $\mathrm{P}$ & $24-27$ & $<30$ & v & $7 a$ \\
\hline P. cambivora & NP & - & - & PR & UN & - & HS & HT & O/tb & A & $\mathrm{P}$ & $24-30$ & $<32 \mathrm{C}$ & $\mathrm{VI}$ & $7 a$ \\
\hline P. europaea & NP & - & - & PR & UN & - & $\mathrm{HS} /-$ & но & $s$ & $\mathrm{P}$ & A & $21-27$ & $<27 \mathrm{C}$ & $\mathrm{VI}$ & $7 a$ \\
\hline P. fragariae & $\mathrm{NP}$ & - & - & PR & UN & - & HS & Hо & $S / t b$ & PIA & P/A & $18-24$ & $<27 \mathrm{C}$ & v & $7 a$ \\
\hline P. rubi & NP & - & - & PR & UN/SS & - & . & Hо & $\mathrm{S} / \mathrm{tb}$ & A & PIA & $15-21$ & $<27 \mathrm{C}$ & v & $7 a$ \\
\hline P. uliginosa & $\mathrm{NP}$ & - & - & PR & UN & - & HS & но & S/tb & PIA & P/A & $15-21$ & $<21 C$ & v & $7 a$ \\
\hline P. cajanip & NP & - & - & PR & UN & - & . & Hо & $\mathrm{s}$ & A & $\mathrm{P}$ & $28-32$ & $<33 C$ & $\mathrm{VI}$ & $7 \mathrm{~b}$ \\
\hline P. cinnamomi & NP & - & - & PR & UN & $\mathrm{CH}$ & HS & HT & $s$ & $A$ & $\mathrm{P}$ & $27-30$ & $<30 \mathrm{C}$ & $\mathrm{VI}$ & $7 \mathrm{~b}$ \\
\hline P. melonis ${ }^{p}$ & $\mathrm{NP}$ & - & - & PR & UN & - & HSI- & HT & $\mathrm{s}$ & A & PIA & $25-28$ & $<35 \mathrm{C}$ & $\mathrm{VI}$ & $7 \mathrm{~b}$ \\
\hline P. pistaciae ${ }^{p}$ & $\mathrm{NP}$ & - & - & PR & UN & . & HS & но & $s$ & PIA & A & $25-30$ & $<33 C$ & v & $7 \mathrm{~b}$ \\
\hline P. sojae & NP & - & - & PR & UN/SS & - & HS & Hо & S/tb & P/A & P/A & $23-30$ & $<33 C$ & v & $7 \mathrm{~b}$ \\
\hline P. vignae ${ }^{p}$ & $\mathrm{NP}$ & - & - & PR & ss & $\mathrm{CH}$ & HS & но & $s$ & A & $A$ & $28-30$ & $>35 \mathrm{C}$ & v & $7 \mathrm{~b}$ \\
\hline $\begin{array}{l}\text { P. cinnamomi var. } \\
\text { parvisporap }^{p}\end{array}$ & $\mathrm{NP}$ & - & - & PR & ss & $\mathrm{CH}$ & HS & HT & $s$ & A & $P$ & $?$ & $<30 \mathrm{C}$ & $\mathrm{VI}$ & $7 \mathrm{~b}$ \\
\hline P. cryptogea & NP & - & - & PR & UN & - & HS & HT & s & A & $\mathrm{P}$ & $24-30$ & $<30 \mathrm{C}$ & $\mathrm{VI}$ & $8 a$ \\
\hline P. drechsleri & NP & - & - & $\mathrm{PR}$ & UN/SS & - & HS & HT & $s$ & A & PIA & $27-33$ & $>35 \mathrm{C}$ & $\mathrm{VI}$ & $8 a$ \\
\hline P. erythroseptica & $\mathrm{NP}$ & - & - & PR & ss & - & HS & но & s & $\mathrm{A}$ & $\mathrm{A}$ & $21-30$ & $<30 C$ & v & $8 a$ \\
\hline P. medicaginis & NP & & - & PR & UN/SS & $\mathrm{CH}$ & HS & HO & s & P/A & PIA & $27-33$ & $<33 \mathrm{C}$ & v & $8 a$ \\
\hline
\end{tabular}

(continued on next page) 
Table 1. (continued from previous page)

\begin{tabular}{|c|c|c|c|c|c|c|c|c|c|c|c|c|c|c|c|}
\hline \multirow[b]{2}{*}{ Species } & \multicolumn{7}{|c|}{ Asexual phase } & \multicolumn{4}{|c|}{ Sexual phase } & \multicolumn{2}{|c|}{ Temperature } & \multirow[b]{2}{*}{ WGn } & \multirow[b]{2}{*}{ Clade $^{\circ}$} \\
\hline & $P A^{a}$ & $\mathrm{Cb}^{\mathrm{b}}$ & PEc & $P^{d}$ & SPOe & $\mathrm{CH}^{\mathrm{f}}$ & $\mathrm{HSg}$ & $\mathrm{Hh}^{\mathrm{h}}$ & OOGi & ANj & OOSk & OPMI & MAXm & & \\
\hline P. sansomeana & NP & - & - & PR & UN & - & HS & HO & s & $P / A$ & P/A & $24-30$ & $<33 \mathrm{C}$ & v & $8 a$ \\
\hline P. trifolii & NP & - & - & PR & UN/SS & - & HS & но & $\mathrm{s}$ & P/A & $A$ & $21-27$ & $<30 \mathrm{C}$ & v & $8 a$ \\
\hline P. brassicae & SP & C & $s$ & - & SSIU & - & HS & HO & $s$ & $P / A$ & A & $15-21$ & $<25 C$ & III & $8 \mathrm{~b}$ \\
\hline P. porrip & SP & - & - & . & ss & . & HS & Hо & s & $P / A$ & A & $15-18$ & $<20$ & III & $8 \mathrm{~b}$ \\
\hline P. primulae ${ }^{p}$ & NP & - & - & . & UN & - & HS & HO & $\mathrm{s}$ & $P / A$ & A & $15-21$ & $<27 \mathrm{C}$ & v & $8 \mathrm{~b}$ \\
\hline P. foliorum & NP/SP & $\mathrm{Cl}-$ & $-/ S$ & PR & ss & $\mathrm{CH} /-$ & . & Hо & $s$ & $\mathrm{P}$ & $P$ & $18-24$ & $<30 \mathrm{C}$ & v & $8 c$ \\
\hline P. hibernalis & $\mathrm{SP}$ & $\mathrm{C}$ & $\mathrm{L}$ & . & UN/SS/U & . & . & но & $s$ & $P / A$ & P/A & $15-21$ & $<25 C$ & III & $8 \mathrm{c}$ \\
\hline P. lateralis & $\mathrm{NP}$ & - & - & PR & SSIUN & $\mathrm{CH}$ & - & $\mathrm{S} / \mathrm{HO}$ & s & $\mathrm{P}$ & $\mathrm{P}$ & $15-24$ & $<26 \mathrm{C}$ & $\mathrm{v}$ & $8 \mathrm{c}$ \\
\hline P. ramorum & SP & $c$ & $s$ & . & ss & $\mathrm{CH}$ & - & HT & $s$ & A & $\mathrm{P}$ & $15-21$ & $<27 \mathrm{C}$ & IV & $8 \mathrm{c}$ \\
\hline P. austrocedrae ${ }^{p}$ & SP & - & . & . & UN & - & HS & но & s & A & A & $15-21$ & $<22 C$ & III & $8 d$ \\
\hline P. obscura & $\mathrm{SP}$ & - & . & . & UN & - & HS & Hо & $s$ & $\mathrm{P}$ & PIA & $20-25$ & $<27 C$ & III & $8 \mathrm{~d}$ \\
\hline P. syringae & $\mathrm{SP}$ & - & - & . & ss & - & HS & Hо & $\mathrm{s}$ & P/A & $P / A$ & $18-24$ & $<24 \mathrm{C}$ & III & $8 d$ \\
\hline P. aquimorbida & NP & - & - & PR & UN & $\mathrm{CH}$ & HS & Hо & S/tb & $\begin{array}{c}\mathrm{A} \\
\text { rare }\end{array}$ & $\mathrm{P}$ & $25-30$ & $<39$ & $\mathrm{v}$ & 9 \\
\hline P. irrigata & NP & - & - & PR & UN & . & . & HT & s & A & $\mathrm{P}$ & $25-30$ & $<30 \mathrm{C}$ & $\mathrm{VI}$ & 9 \\
\hline P. hydropathica & NP & - & - & PR & UN & $\mathrm{CH}$ & HS & HT & $s$ & $P / A$ & $\mathrm{P}$ & $25-30$ & $<37$ & $\mathrm{VI}$ & 9 \\
\hline P. parsiana & NP & - & - & PR & UN & - & HS & HT & $s$ & A & A & $25-30$ & $<35 C$ & $\mathrm{VI}$ & 9 \\
\hline P. chrysanthemi & $\mathrm{NP}$ & - & - & PR & $?$ & $\mathrm{CH}$ & HS & но & $s$ & $P / A$ & A & $24-30$ & $<35 \mathrm{C}$ & v & 9 \\
\hline P. polonica & $\mathrm{NP}$ & - & - & PR & UN & $\mathrm{CH}$ & HS & HO & $s$ & PIA & $\mathrm{P} / \mathrm{A}$ & $24-27$ & $<33 \mathrm{C}$ & v & 9 \\
\hline$P$. insolita & NP & - & - & PR & UN & - & HS & $\mathrm{S} / \mathrm{HO}$ & $\mathrm{s} ?$ & . & $\mathrm{P}$ ? & $33-36$ & $<36 \mathrm{C}$ & $\mathrm{v}$ & 9 \\
\hline P. captiosap & $\mathrm{NP}$ & - & - & PR & UN? & - & - & Hо & $s$ & A & PIA & $18-24$ & $<27 \mathrm{C}$ & v & 9 \\
\hline P. fallax & $\mathrm{NP}$ & - & - & PR & ss & $\mathrm{CH} /-$ & . & Hо & $s$ & $P / A$ & P/A & $15-20$ & $<25 C$ & v & 9 \\
\hline P. constricta & $\mathrm{NP}$ & - & - & PR & UN.gs & - & - & Hо & S/tb & $\mathrm{P}$ & P/A & $20-22$ & $<32 C$ & $\mathrm{v}$ & 9 \\
\hline P. richardiae & NP & - & - & PR & UN & - & HS & но & s & P/A & $\mathrm{P}$ & $20-24$ & $<31 \mathrm{C}$ & v & 9 \\
\hline P. macrochlamydosporap & NP/SP & - & 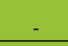 & PR & UN & $\mathrm{CH}$ & HS & $s$ & - & - & - & 23-30 & $<36 \mathrm{C}$ & VI? & 9 \\
\hline P. quininea ${ }^{p}$ & NP & - & - & . & ss & . & HS & $s$ & - & - & - & $22-27$ & $<30 \mathrm{C}$ & VI? & 9 \\
\hline P. kernoviae ${ }^{p}$ & $\mathbf{P}$ & $\mathrm{C}$ & M & . & SSIUN & - & - & но & S/tb & P/A & $\mathrm{P}$ & $18-20$ & $<26 \mathrm{C}$ & 1 & 10 \\
\hline P. morindae & $\mathrm{P}$ & C & M/L & - & $u$ & - & - & Hо & S/tb & $P / A$ & P/A & $21-27$ & $<27 \mathrm{C}$ & 1 & 10 \\
\hline P. boehmeriae ${ }^{p}$ & $\mathbf{P}$ & $c$ & $s$ & . & UN & - & - & Hо & s & A & PIA & $21-27$ & $<28 \mathrm{C}$ & 1 & 10 \\
\hline P. gallica & NP & - & - & PR & UN & $\mathrm{CH}$ & HS & s & - & - & - & $20-21$ & $<24$ & VI? & 10 \\
\hline
\end{tabular}

No specimens available in culture collections

\begin{tabular}{|c|c|c|c|c|c|c|c|c|c|c|c|c|c|c|c|}
\hline P. japonicap & NP & - & - & PR & SS & - & HS & HT & $\mathrm{s}$ & $\mathrm{P} / \mathrm{A}$ & A? & $24-27$ & $<30 \mathrm{C}$ & VI & ND \\
\hline P. italicap & $\mathbf{P}$ & - & - & $=$ & UN & $\mathrm{CH} /-$ & $=$ & $\mathrm{HO}$ & S & $\mathbf{P}$ & A & $22-26$ & $<35 \mathrm{C}$ & 1 & ND \\
\hline
\end{tabular}

Have not been cultured, described based on morphological features observed in infected tissue.

\begin{tabular}{|c|c|c|c|c|c|c|c|c|c|c|c|c|c|c|c|}
\hline P. leersiae & \multicolumn{7}{|c|}{ ABSENT } & HO & $S$ & $\mathrm{P}$ & $\mathrm{A}$ & ND & ND & $?$ & ND \\
\hline P. oryzo-bladis & NP & - & - & PR & UN/SS & - & $\cdot$ & $\mathrm{HO}$ & $S$ & A & PIA & ND & ND & V & ND \\
\hline P. polygonip & SP & $\mathrm{C}$ & M & $=$ & UN/SS & $\mathrm{CH} /-$ & - & $\mathrm{HO}$ & $S$ & $\mathbf{P}$ & A & ND & ND & III & ND \\
\hline P. verrucosa & NP & - & - & - & SS & - & HS & $\mathrm{HO}$ & $S$ & PIA & P/A & ND & ND & V & ND \\
\hline P. cyperi & SP & - & - & $=$ & SS & - & HS & $\mathrm{HO}$ & S & PIA & A & ND & ND & III & ND \\
\hline P. cyperi-bulbosi & SP & C & $S$ & - & SS & - & - & $\mathrm{HO}$ & 0 & $P$ & $P$ & ND & ND & III & ND \\
\hline$P$. eriugena & $\mathbf{P}$ & - & - & - & SS & - & HS & $\mathrm{HO}$ & $\mathrm{S}$ & $\mathrm{P} / \mathrm{A}$ & A & ND & ND & III & ND \\
\hline P. lepironiae & SP & C & M & - & UN & - & - & $\mathrm{HO}$ & $S$ & $\mathbf{P}$ & $\mathbf{P}$ & ND & ND & III & ND \\
\hline
\end{tabular}

Designed by Z. Gloria Abad USDA-APHI-CPHST

While the overall phylogeny of the genus has been clarified by multigene analysis, ambiguities still remain for some closely related groupings, and there is taxonomic uncertainty with some morphologically similar species complexes. In the last few years, clarification of the $P$. megasperma complex (43) and other clade 6 species have been the focus of several labs with species such as $P$. fulvialis, $P$. gibbosa, $P$. gregata, $P$. litoralis, $P$. pinifolia, $P$. rosacearum, and $P$. thermophila recently described $(75,109,152,154)$. There are also a number of clade 6 provisional species awaiting further analysis and formal species description (P. taxon PgChla- mydo, $P$. taxon raspberry, $P$. taxon salixsoil, $P$. taxon canalensis, $P$. taxon erwinii, $P$. taxon hungarica, $P$. taxon oregonsis, and $P$. taxon paludosa). Likewise, $P$. cryptogea and $P$. drechsleri have long been a challenge to differentiate based on morphological features alone (reviewed in Erwin and Ribeiro, 82), and while different groupings were observed based on isozyme (204) and ITS phylogenetic analysis (87), taxonomic clarity has been elusive. The multigene analysis of Mostowfizadeh-Ghalamfarsa et al. (209) confirmed that while $P$. drechsleri was monophyletic, the $P$. cryptogea complex formed 3 well-defined phylogenetic groups, with group I closely 
affiliated with $P$. erythroseptica and groups II and III together on a basal clade. Some isolates were intermediate between groups II and III and exhibited a greater amount of heterozygous bases than the other isolates, suggesting possible outcrossing between these groups. Additional analysis including the holotype strain of $P$. cryptogea is needed to identify the clade representing the sensu stricto classification of this species as well as the correct taxonomic classification of the remaining clades and if hybridization between them is occurring. Using a parsimony-based ancestral recombination graph (ARG) and genealogies inferred from the $\beta$ tubulin and translation elongation factor $1-\alpha$ genes, Olson et al. (219) suggested that divergence between $P$. cryptogea and $P$. drechsleri was recent and that speciation is still in progress, a possibility that deserves further examination.

$P$. citricola is another species complex where prior isozyme (221) and SSCP analysis (161) suggested multiple species, and more recent multigene phylogenetic analysis separated out the new species P. plurivora (151), P. multivora (247), P. capensis (24), P. elongata (228), and possibly other new species (151). While a recent taxonomic evaluation has re-elevated $P$. pini to a valid species description (120), there are still several taxonomic subgroups such as $P$. citricola clade E (120) and $P$. taxon emzansi (reviewed in Bezuidenhout et al., 24) yet to be fully characterized. Isozyme and molecular analysis confirm that other species such as $P$. citrophthora (201) and P. capsici $(39,200)$ are complexes composed of more than one species. An effort to delineate species boundaries in a number of these and several other species complexes, as well as describe new species using multilocus phylogenetic analysis, is in progress in several labs and will hopefully provide better resolution that is needed in the not too distant future.

Characterizing hybrid populations. In the laboratory, interspecific hybrids have been generated between P. capsici and P. nicotianae by zoospore fusion (79) and transfer of isolated nuclei (106), and between $P$. infestans and $P$. mirabilis (99), $P$. capsici and $P$. tropicalis (70), and P. sojae and P. vignae (199) in sexual crosses. In the field, hybrids have been recovered for $P$. nicotianae and $P$. cactorum $(37,128,189), P$. cactorum and $P$. hedraiandra (187), and $P$. cactorum and $P$. nicotianae $(P . \times$ pelgrandis, 214$)$. $P$. andina is a naturally occurring hybrid with $P$. infestans and an unknown species as the parents (101). Perhaps the most notable natural hybrid is $P$. alni, which is associated with alder dieback in Europe $(42,65)$. The most common form is Phytophthora alni subsp. alni, while other variants are collectively known as $P$. alni subsp. uniformis and $P$. alni subsp. multiformis. While the parentage of these hybrids was thought to be species closely related to $P$. cambivora and $P$. fragariae, more recent analysis suggests that $P$. alni subsp. alni is derived from several hybridization events between $P$. alni subsp. uniformis and P. alni subsp. multiformis (133). In addition to the characterized hybrids described above, "hybrid swarms" as described by Burgess et al. (47) may also occur in nature. Hybrid swarms among natural Phytophthora populations contain mixtures of parent, offspring, and intermediate types with high tendencies for backcrossing and outcrossing. Their work with clade 6 isolates recovered from native ecosystems in Western Australia identified different alleles of the ITS rDNA repeat unit in single isolates that also possessed a polymorphic coxl gene. They concluded that the presence of such hybrid swarms is indicative of sexual and somatic hybridization events; the high proportion of these variant isolates within the population also implied that these hybridization events were common.

Hybrid species represent a major challenge in the development of robust diagnostic protocols. This is especially true if the target for the diagnostic marker is encoded on the mitochondrial DNA, as this is uniparentally inherited from the maternal parent $(86,291)$. Diagnostic protocols using species-specific PCR markers that include both a nuclear and mitochondrial locus may suggest the hybrid nature of an isolate if there is a lack of agreement between the two loci. Other techniques that allow for identification of multiple species at the same time, such as macro/micro arrays, SSCP, or sequence-based identification, are typically better at identifying hybrid isolates.
Isolation of Phytophthora spp.

Selective media for isolation usually consists of cornmeal agar (CMA) or clarified V8 juice agar (cV8) amended with a combination of antibiotics including pimaricin, ampicillin, rifampicin, vancomycin, nystatin, and fungicides pentachloronitrobenzene (PCNB) and hymexazol (also known as Tachigaren) (reviewed in Erwin and Ribeiro, 82). The selective activity of these media is mainly due to pimaricin or nystatin, both active against most Eumycotan fungi. The selective media are light sensitive and thus should be kept in darkness. Hymexazol inhibits most Pythium and Morteriella species (the only genus in Mucorales which contains species insensitive to pimaricin and other polyene antibiotics), which can overgrow and mask Phytophthora (276). There are several Pythium spp. that are resistant to hymexazol and some Phytophthora spp. that are sensitive; thus adjustment of the concentration might be required $(7,108,118)$. For bacterial management, the combination of rifampicin and ampicillin was found to be more effective than vancomycin alone (145). The selective media "favors" the growth of Phytophthora but does not guarantee successful isolation. Important consideration should also be given to the quality (newer actively growing infection versus older infection) or type of sample material from which isolation is attempted (bark, leaf, soil, or water). For additional information on selective medium and techniques for isolation, see Mitchell and KannwischerMitchell (208) and Erwin and Ribeiro (82).

Isolation from soil and water. A wide range of methods have been reported for the successful isolation of Phytophthora from soil and water samples, including soil plating or baiting methods. Due to the limited amount of soil that can be deposited on the agar surface, direct soil plating is typically utilized when Phytophthora inoculum is high and is not suitable for recovery of some species that give rise to few viable propagules per gram of soil, such as $P$. cinnamomi (117). Soil baiting has several advantages over direct plating. First, a larger volume of soil can be tested, increasing the likelihood of detecting species present at a low population density. Secondly, homothallic species that survive as dormant oospores are more likely to be detected by baiting than by direct plating (83). Soil baiting involves the flotation of zoospore-attractive baits in soil-water suspensions, typically requiring $2 \times$ the amount of distilled water as soil, or a lower water/soil ratio in cases where the inoculum level is low $(18,150,274)$. Zoospores swim upward and colonize these baits, which are then washed under distilled or tap water (mainly to eliminate bacteria buildup on the bait surface), blotted dry, and sections with discoloration are placed in selective media. Success of isolation from soil is often increased when soil is kept between 15 and $20^{\circ} \mathrm{C}$ and the bait is not wounded, which discourages colonization by Pythium spp. and bacteria $(83,92,130$, reviewed in 82,144). False negatives can be avoided when soils are re-baited after air-drying, premoistening, or cold storage practices that induce germination of dormant spores $(18,64,144,268)$. It should be noted that populations of Phytophthora spp. may fluctuate depending on the season $(19,20,115,202,290)$, so samples may need to be collected at different times of the year to get an accurate picture of population density or for detection purposes. Leaf tissue for bait material has been preferred in most recent studies rather than apple, pear, or lemon fruit reported in historical records (82). A wide variety of plant foliage has been utilized (274), although not every type of bait is equally attractive to diverse Phytophthora spp. Leaves of Camellia, Rhododendron, and Quercus spp. have been more commonly used in recent years $(18,84,92,150$, $229,257,260$ ). Leaves with little or no trichomes enable direct contact with water during the baiting routine. Observation of discoloration is best on young tissues such as leaflets, cotyledons, and radicles. These baits have another advantage over "leathery" baits by enabling the examination of sporangia under a light microscope.

Protocols involving slight variation in filtration and baiting techniques also exist for isolation of Phytophthora spp. from water samples with leaf or fruit baits being placed in a mesh bag and 
flooded in water (e.g., stream) for a period of time. The retrieval time depends greatly on water temperature; with temperatures exceeding $15^{\circ} \mathrm{C}$ the infection process can be rather quick (3 to 7 days) (130). Foliage of evergreen plants such as rhododendron, Ilex sp., or Lithocarpus densiflorus with thick-leathery structure appears to be more suitable compared to brittle leaves that can be rapidly colonized by diverse organisms. However, no difference was found among evergreen leaves in baiting a diverse range of species in streams (229), although Ghimire et al. (92) reported that rhododendron leaves yielded the greatest diversity and population of species. In addition to baiting, 3 or $5 \mu \mathrm{m}$ pore sized nitrocellulose or polycarbonate filters have been used to isolate Phytophthora spp. from water $(121,130,229)$. If water is murky and contains large organic particles, prefiltering with cheesecloth or miracloth may be necessary. Once water is filtered, the filter is placed face-down on selective media and the plates are incubated for 1 to 3 days. Filters are then removed and the media examined daily for colonies typical for Phytophthora spp. and subcultured. Similar to direct soil plating, filtration of water samples can be done with a limited amount of water (50 to $200 \mathrm{ml}$ per filter). Therefore, repeated and systematic sampling of streams and soil within an area will be needed to reveal the true biodiversity of Phytophthora spp. (131). The USDA-APHIS has an approved procedure for recovery of $P$. ramorum from water samples (http://www.aphis.usda.gov/plant_health/plant_pest_info/pram/down loads/surveyplan/appendixI.pdf).

Isolation from plant tissue. Isolation of Phytophthora spp. is achieved from lesions without surface sterilization when infection is active and samples are taken from the advancing lesion margin $(149,151,255,275)$. The success of isolation from necrotic tissues can be decreased by the presence of antagonistic bacteria and phenolic compounds produced by the plant that inhibit growth of Phytophthora spp. With plants that produce high amounts of phenolic compounds, such as Alnus sp., repeated washing and plating numerous infected tissue samples on selective media can increase the chances of isolation of the target Phytophthora spp. $(124,149,148,255)$. Tissue samples should be blotted dry using filter paper before plating to discourage bacteria buildup. If surface disinfestation is attempted, particularly from tissue with advanced necrosis, 30 seconds of exposure to $70 \%$ ethanol (ethanol does not leave residue and there is no need for washing when compared to the use of sodium hypochlorite) followed by drying on filter paper appears to be sufficient. With evergreen plants, leaf colonization by saprophytic organisms is much slower compared to deciduous plants, thus providing a longer window for isolation. For example, $P$. ramorum was still recovered from older necrotic areas of inoculated evergreen foliage of rhododendron and bay laurel (Umbellularia californica) after 49 weeks (85).

\section{Approaches for Morphological Identification}

Identification of many Phytophthora species can be relatively straightforward; however, overlapping morphological features and intra-specific variability can make Phytophthora a difficult genus for species identification (82). It is important to start the process with clean cultures obtained using an appropriate selective medium (noted above). Placing a transfer plug with mycelium in a sterile petri plate and overlaying with a block of selective medium on top can be helpful to clean up most bacterial or fungal contaminants. The hyphae will grow through the medium toward the surface free of bacteria; subsequent transfer to nutrient agar can be used to verify if the isolate is free of bacterial contamination. Hyphal tips of clean cultures are then transferred and maintained commonly on media such as CMA, cV8, potato dextrose agar (PDA30; Difco using $30 \mathrm{~g}$ instead of the $37 \mathrm{~g} /$ liter indicated by the vendor), lima bean agar (LBA), carrot agar (CA), oatmeal agar, rye agar, and hempseed agar depending on the species (see Erwin and Riberio, 82). Another effective method to eliminate bacterial contamination is to inoculate a leaf (i.e., rhododendron) or fruit (i.e., apple, pepper) and isolate the organism from resulting lesions.

The growth medium of choice is particularly important for con- sistency in species description and identification purposes. Commonly utilized media include V8 juice agar for growth-temperature relationship and morphological features and $\mathrm{CMA}, \mathrm{cV} 8$, and PDA30 for colony pattern. For evaluating sporangia morphology and size measurements, liquid culture should be utilized. For this purpose, a plug (ca. $0.5 \mathrm{~cm}^{2}$ ) taken from the margin of an actively growing isolate is transferred to a new petri dish and flooded with tap water, distilled water, $10 \%$ sterile or nonsterile soil extract solution, pond water, rain water, or river water $(82,88)$. Isolates can be incubated at room temperature on the lab bench, but under white fluorescent light they may exhibit more consistent production of sporangia $(82,88)$. For some species, nonsterilized liquids or sprinkling nonsterile soil on water cultures can induce sporangial formation. Plugs are observed under a compound microscope after 12 to $24 \mathrm{~h}$; if sporangia have not formed, remove the liquid and repeat the flooding and incubation (88). When measuring sporangia size, attention should be paid to whether they are fully developed (individual zoospores are recognizable within the sporangia cytoplasm) and whether they are the first produced sporangia. The size of secondary produced sporangia becomes smaller, particularly with species with nested proliferation (see below). To ensure that statistically supported measurements are obtained, the number of sporangia that are measured should be between 20 and 50. To determine the persistence (caducity) of sporangia, sporulating agar plugs of mycelium are removed from the liquid culture, placed in contact with a microscope slide containing a drop of water, and moved briskly to dislodge sporangia. If the species is caducous, many dislodged sporangia with pedicels will be observed under the microscope.

A listing of the 117 described species in the genus with their morphological features used in making taxonomic classifications are presented in Table 1 (29 of these are exotic and of concern to the USDA-APHIS regulatory personnel, 246). The most robust character to start the morphological identification of species is the thickness of papilla of the sporangium, classified as papillate (papilla size $\geq 3.5 \mu \mathrm{m}$ ) (Fig. 2A to D), semipapillate (papilla size $<3.5$ $\mu \mathrm{m})$ (Fig. 2E to $\mathrm{G}$ ), and nonpapillate (Fig. $2 \mathrm{H}$ ) with very slight apical thickening (Table 1). A "natural arrangement" of the species by the type of papilla, with some exceptions, is observed in the groupings of a phylogenetic analysis $(32,165,195,196)$. Clades 1 to 5 include papillate and semipapillate species; Clades 6, 7, 9, and subclade 8a contain nonpapillate species; Subclades 8b, 8c contain a mix of semipapillate and nonpapillate; and Clade 10 contains a mix of papillate and the nonpapillate species. Another useful feature for identification is the caducity of the sporangia and the length of the pedicel (short: less than $5 \mu \mathrm{m}$ [Fig. 2B and E], medium: between 5 and $20 \mu \mathrm{m}$ [Fig. $2 \mathrm{C}$ and F], or long: greater than $20 \mu \mathrm{m}$ [Fig. 2D and G]). Almost all nonpapillate species have persistent sporangia (Fig. $2 \mathrm{H}$ ) except $P$. pinifolia, which is partially caducous with a medium pedicel (75), and $P$. foliorum, which is partially caducous with a short pedicel (69). Another consistent character for identification is the proliferation of the sporangia (internal, external, or nested [Fig. 2I and J]). Most papillate and semipapillate species do not show internal proliferation except $P$. multivesiculata (132) and P. plurivora (151). Most nonpapillate species have proliferating sporangia except $P$. rosacearum (109), $P$. pinifolia (75), P. primulae (263), and $P$. quininea (62). Sporangial shape (ovoid, obovoid, pyriform, obpyriform, clavate, obclavate, reniform, irregular), size (length-breadth ratios), and base (tapered or rounded) are other important features for identification $(82,88)$. Most Phytophthora spp. show variation in sporangia shape; thus the most common types should be identified and measured. Branching of sporangiophores (unbranched, with globose swellings, close sympodial, simple sympodial, compound sympodial, umbellate, and irregularly branched) in liquid cultures or agar needs also to be noted for identification (Fig. 2K to N). Sporangiophore shape is not a very informative character for identification, with the exception of the umbellate type sporangiophores that are only produced by the papillate species $P$. tropicalis $(11)($ Fig. $2 \mathrm{~N}$ ) in Clade 2a and P. morindae (212) in Clade 10. The semipapillate 

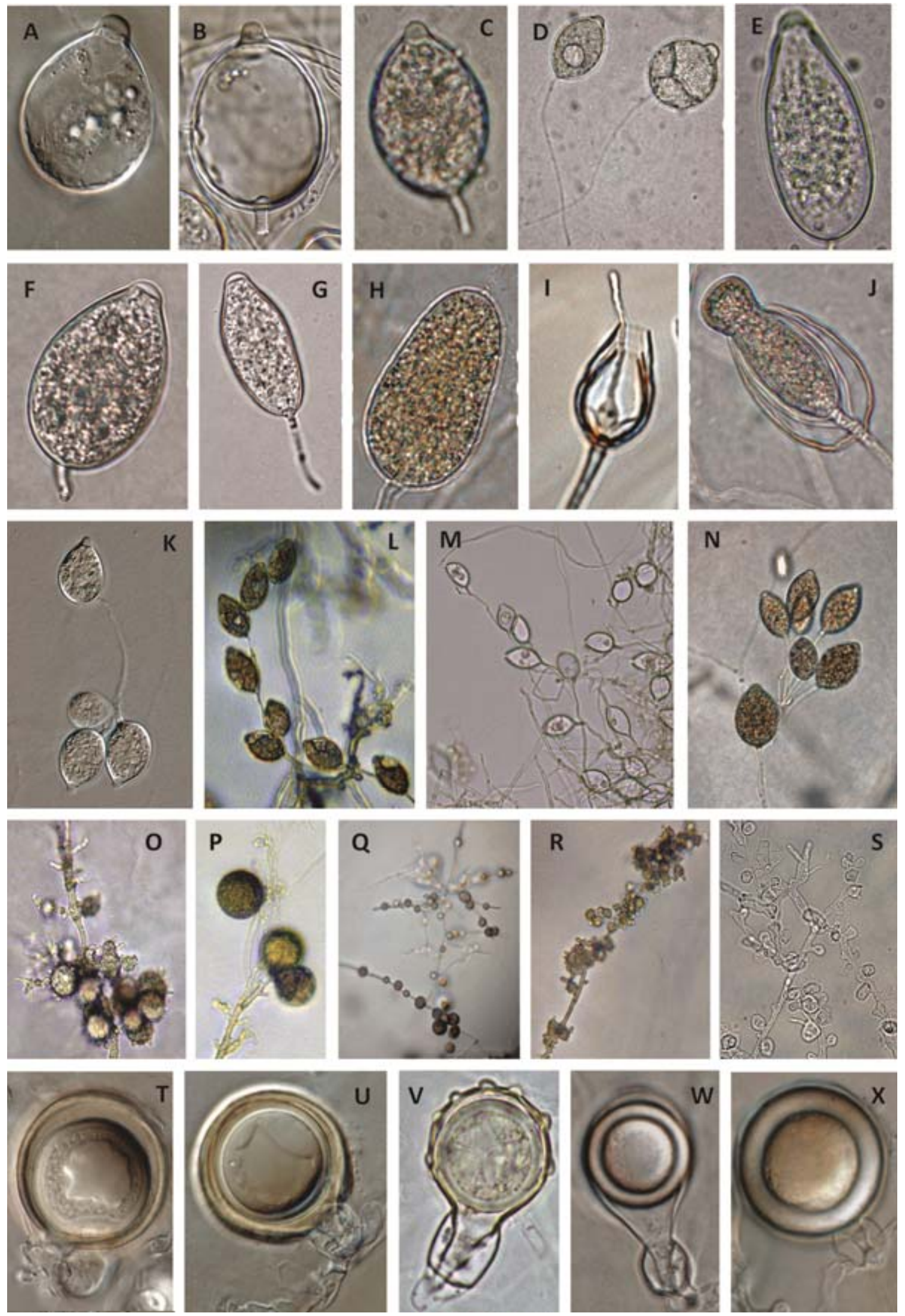

Fig. 2. Morphological features of Phytophthora species asexual and sexual stage. $\mathbf{A}$ to $\mathbf{H}$, Sporangia papilla and pedicel. $\mathbf{A}$ to $\mathbf{D}=$ Papillate: $\mathbf{A}, P$. idaei (persistent); $\mathbf{B}, P$. boehmeriae (short); C, P. kernoviae (medium); D, P. capcisi (long). E to $\mathbf{G}=$ Semi-papillate: E, P. ramorum (short); $\mathbf{F}$, P. nemorosa (medium); $\mathbf{G}, P$. hibernalis (long). $\mathbf{H}=$ Nonpapillate $P$. cinnamomi var. parvispora. I and J, Sporangium proliferation. $\mathbf{K}$ to $\mathbf{N}$, Sporangiophore. $\mathbf{K}$ to $\mathbf{M}=$ Simple sympodial: $\mathbf{K}, P$. boehmeriae; $\mathbf{L}, P$. ramorum; $\mathbf{M}, P$. kernoviae; N, Umbella Type P. tropicalis. Chlamydospores: O, P. cinnamomi; P, P. ramorum. Hyphal swellings: Q, P. drechsleri; R, P. taxon kelmania; S, P. foliorum. Paragynous antherium: T, P. tentaculata. Amphyginous antheridium: U, $P$. idaei. Wall projections: V, P. cambivora. Oogonium with tapered base: W, $P$. hevea. Oospore with thick wall: X, P. kernoviae. Photos by Z. G. Abad, USDA-APHIS-CPHST. 
P. hibernalis produces irregular sympodium and occasionally umbellate sporangiophores.

Chlamydospores are thick-walled, long-term survival spores delimited from the mycelium by septa. Presence (or occasional presence), position (lateral, terminal, or intercalary), and shape (globose, subglobose, or elongate) are diagnostic features of chlamydospores that support identification (Fig. $2 \mathrm{O}$ and P). In contrast, hyphal swellings are thin-walled bodies not delimited by septa and may be variable in shape. The presence (or occasional presence), shape (globose, subglobose, elongate, obovate, obpyriform, distorted shapes, catenulate, radiate, and clustered), position (terminal and intercalary), and formation of chain-like clusters are features useful in identification (Fig. 2Q to S). Although hyphal swellings are not strong characters for species differentiation, they can be useful in the identification of some species such as in the $P$. cryptogea/P. drechsleri "complex".

Determination of the sexual stage of Phytophthora is the second most important morphological feature and involves the production of the oospores through the fusion of the oogonium and antheridium (maternal and paternal gametangia, respectively). Homothallic species produce oogonia in single cultures, while heterothallic species produce them in the presence of a strain of the opposing compatibility type (A1 or A2). The addition of sterols to the growth medium was originally considered to be essential to sexual reproduction in pythiaceous fungi $(77,116)$; however, several fatty acids, including palmitoleic, followed by oleic, palmitic, and linoleic, also stimulate oospore formation in certain species of Phytophthora $(143,159)$. We have successfully used UDO Oil (made with organic flax, sesame, and sunflower seed oils; Flora, Inc., Lynden, WA, USA) at a rate of $200 \mu \mathrm{l} / 400 \mathrm{ml}$ in hempseed agarbased media to stimulate oospore production at $20^{\circ} \mathrm{C}$ in darkness ( $\mathrm{Z}$ Gloria Abad, unpublished). For the production of the sexual stage on agar medium, a mycelial plug of the unknown isolate is cultured individually in LBA to determine if it is homothallic. If oospores are not produced, the unknown culture is placed on one side of the agar plate and a plug of a tester strain (A1 or A2) on the other side. Intra- and interspecific pairings with testers (A1 and A2), including P. cambivora, P. capsici, P. cryptogea, P. drechsleri, $P$. meadii, $P$. nicotianae, $P$. tropicalis, and other heterothallic species, can be used. A number of media noted above amended with the above-mentioned fatty acids are appropriate for mating type tests. The polycarbonate membrane method described by Ko (157) facilitates identification and genetic studies of heterothallic species of Phytophthora. The sexual structures can be formed in interspecific pairings across the polycarbonate membrane by hormonal influence of the opposing mating type $(157,158)$. The sexual stage usually forms in the dark and at temperatures lower than the optimum temperature for growth (e.g., $20^{\circ} \mathrm{C}$ ). Production of oospores can occur in approximately one week up to months depending on the species. The use of agarose instead of agar is reported to favor the production of increased numbers of oospores (157).

Of the 117 reported Phytophthora species, the majority are homothallic (Table 1). A few nonpapillate species are self-sterile, and the production of their sexual phase has not been observed; these include $P$. litoralis and $P$. pinifolia in Clade $6(75,154), P$. machrochlamydospora and $P$. quininea in Clade $9(62,138), P$. gallica in Clade 10 (153), and P. gemini (188). There are no papillate or semipapillate species reported to be self-sterile. P. gonapodyides, $P$. thermophila, and $P$. lateralis are self-sterile or can produce gametangia under special conditions $(10,45,154,277)$. $P$. leersiae is the only species reported to produce only the sexual stage (119). Some heterothallic species (i.e., P. capsici) can occasionally be self-fertile in single culture (especially in fresh isolates without many transfers; Z. Gloria Abad, personal communication).

Antheridia in Phytophthora can be either paragynous or amphigynous. A paragynous antheridium is formed when the antheridial hyphae oppresses laterally to the oogonial stalk (Fig. 2T). An amphigynous antheridium is formed when the oogonial hyphae grows through the antheridial hyphae forming a kind of collar that surrounds to the antheridial stalk (Fig. 2U). Some species produce consistently one type of antheridia, whereas several species produce both types and can be predominantly amphyginous or predominantly paragynous (Table 1). Almost all heterothallic species have amphigynous antheridia except $P$. hydropathica, which produces both types of antheridia (122). P. japonica, described by Waterhouse (288), was reported to be a heterothallic species that produced both amphigynous and paragynous antheridia, but the type culture of this species was lost. A few species may have multiple antheridia, such as $P$. glovera, which produces both paragynous and amphigynous types on a single oogonium (2). P. insolita is the only species of Phytophthora where no antheridium is seen despite the production of oospores.

A few Phytophthora species have ornamented oogonial walls (Fig. 2V), including P. alni subsp. alni, subsp. multiformis, and subsp. uniformis (44), P. cambivora, P. katsurae, and P. cyperibulbosi (82). Some species produce oogonia with tapered bases (Fig. 2W; Table 1). Oospores can be plerotic if the oogonium is filled (Fig. 2X), or aplerotic if there is space left between the oospore wall and the oogonium (Fig. 2T). Some species, like $P$. kernoviae and $P$. morindae, have very thick walls at early stages (Fig. 2X) that become thinner with the maturation of the oospore. The oospore shape is not a strong character for species identification. The optimum and maximum temperature for growth can be additional information to support the identification of species (Table 1).

Although Phytophthora is one of the most studied genera of plant pathogens, there is limited information in international herbaria and culture collections on the accession numbers used for the types $($ Holotype $=$ dry specimen; Ex-holotype $=$ original culture $)$. Likewise, publications on morphological or molecular taxonomy do not always include this information. Although considerable advances in molecular systematics have been made in the last 10 years, there is still confusion when identifying isolates of some described species, recognizing new species, and clarification of species complexes. This confusion is due in part to the number of sequences in GenBank from misidentified cultures or poorly annotated sequences as well as a lack of an ex-holotype culture in the analysis. The "Type" or "Holotype" defines the species, and if this primary specimen is lost, the information for the Lectotype or Neotype (representative of species when original description based on syntypes or when the holotype is no longer available, respectively) is fundamental for the correct recognition of species. In order to develop accurate systematics (taxonomy, nomenclature, and phylogenetics), it is very important that the rules established by the International Code of Nomenclature for algae, fungi, and plants (ICN) Melbourne Code 2011 (formerly International Code of Botanical Nomenclature [ICBN]) are followed and that the importance of the Types are recognized (1).

\section{Approaches for Molecular Identification}

A variety of molecular techniques have been used for speciesand subspecies-level identification ranging from the technologically complex to simpler procedures requiring less technical skill or sophisticated equipment.

Sequence-based species identification. The most accurate molecular method for identification of isolates to a species level is accomplished by sequence analysis of specific loci. Historically, the ITS region has been used, and since there is a large dataset for this locus that includes all described species, it continues to be a mainstay for this purpose. However, this is not the optimal locus for all species, particularly those that are phylogenetically closely related (for example, $P$. rubi and $P$. fragariae have identical ITS sequences; some Clade 1c species cannot be differentiated with this locus). More recently, a number of alternative nuclear (60S ribosomal protein L10, $\beta$-tubulin, enolase, HS protein 90, large subunit rRNA, TigA gene fusion, translation elongation factor $1 \alpha$; $32,165,283$ ) and mitochondrial (cox1, nad1, $\operatorname{cox} 2, \operatorname{nad} 9, \operatorname{rps} 10$, and sec $Y ; 165,191,193,195,196)$ loci have been sequenced for phylogenetic resolution within Phytophthora that are also useful for identification purposes. Background information for amplification 
and sequencing of many of these loci, as well as the capability for BLAST searches against a curated database for isolate identification, may be found at the Phytophthora Database (www. phytophthoradb.org). When conducting BLAST analyses, it is important to use a curated dataset to ensure sequences reflect accurate species classification. A dataset for ITS and coxl and 2 spacer sequences is also available at Phytophthora ID (105) (www.phytophthora-id.org) and sequence data for several loci (ITS, $\beta$-tubulin, elongation factor $1 \alpha$, or $\operatorname{cox} 1$ ), along with pictures of morphological features, may be found at Q-Bank (www.qbank.eu). The ITS region, along with a portion of the coxl gene, have also been proposed as the two loci to include in the Barcode of Life Database (www.boldsystems.org), and representative sequences for all described and some provisional species have been deposited (232). To support the classification of a new species, it is important that sequences from several of the above-noted loci are generated.

While BLAST analysis can be an effective tool for identifying isolates to a species level, there are several considerations to keep in mind to ensure sequence-based results are accurate (155). BLAST scores are commonly used to evaluate classification of isolates, but since these scores are dependent on the length of the aligned sequences as well as the amount of sequence identity, there will be instances where high levels of sequence identity for only a portion of the target sequence may provide an incorrect impression of species classification. Also, it is common to encounter results where the scores are similar for comparisons with different species, which makes it difficult to draw conclusions on species identification. While it is possible that the unidentified isolate may represent a new species, if the locus is known to exhibit intraspecific polymorphisms it could also represent an example where clear delineations among closely related species cannot be made with this region. For identification of Trichoderma spp. using the ITS region, this problem was addressed by determining which regions were invariant at the intraspecific level and using only those for BLAST analysis (72); with the extent of the ITS dataset available, this approach could also be employed with Phytophthora. Heterozygosity may also complicate efforts at identification with nuclear loci, and while this may be reflective of outcrossing of a diploid organism (e.g., P. capsici), it may also represent an interspecific hybrid (having the two alleles group separately in phylogenic analysis would be indicative of this). It also is important to recognize that the taxonomic classification of the genus has not yet caught up with phylogeny; there are species complexes with closely related species where morphological features alone are not enough to delineate species boundaries observed from phylogenic analysis (examples discussed above). Until these complexes are subjected to detailed multilocus analyses using isolates representing the diversity observed in nature, identification by sequence analysis alone will continue to be problematic for some species. Comparing results from several loci is necessary to confirm species identification, especially when working with species complexes.

Gel-based molecular techniques for species identification. There are several gel-based techniques that can be used to identify isolates to a species level using amplicons generated by PCR. Ristaino et al. (231) observed that amplification of the ITS region followed by digestion with restriction enzymes generated restriction profiles that could be useful for identification to a species level. The use of PCR-restriction fragment length polymorphism (RFLP) of the ITS region for species identification was expanded by Cooke et al. (59). Using this approach, Camele et al. (51) characterized isolates from Italy, Bowman et al. (40) differentiated $P$. palmivora from $P$. nicotianae, and, coupled with sequence analysis of the ITS region, Roy et al. (233) examined Phytophthora spp. in Eastern India. Drenth et al. (71) improved the technique by developing primers that were specific for Phytophthora, allowing amplifications to be done directly from environmental samples.

In addition to the ITS region, PCR-RFLP analysis of the coxl and $\operatorname{cox} 2$ gene clusters has been found useful for species identification (197). While this technique cannot be used with DNA ex- tracted from infected plant tissue (the amplification primers are not specific for Phytophthora), another primer pair (Phy-8b and Phy10b) spanning the spacer region and containing portions of the flanking coxl and cox 2 genes is specific for amplification of Phytophthora spp. (they do not amplify plants or the closely related genus Pythium, 198) and hence can be used for amplification from infected plant tissue. When the pathogen DNA concentration is low it may take two rounds of amplification to observe a visible band in a gel. The amplicon size varies among species but is generally less the $0.5 \mathrm{~kb}$, and single digestion with ApoI and DraI can differentiate many but not all species (F. Martin, unpublished).

SSCP analysis of the ITS region of the rDNA is another gelbased method found useful for species identification (161). The ITS-1 region is amplified, denatured, and separated on a nondenaturing polyacrylamide gel with the resulting banding profiles useful for species identification. A technique for direct colony amplification of the ITS-1 region has been published (163). The spacer region between the cox 1 and $\operatorname{cox} 2$ genes has also been used with this technique (229). An overview of SSCP migration patterns for 60 species in the genus Phytophthora, along with morphological keys and photomicrographs, may be found in Gallegly and Hong (88). The technique has been modified by Tom Kubisiak using an automated sequencer for data collection, thereby improving accuracy of the data and simplifying its analysis and comparison among isolates (reviewed in Martin et al., 194; the online eXtra of this cited article has the techniques). Ghimire et al. (92) used SSCP to identify species recovered from irrigation runoff containment basins.

Molecular techniques for population analysis. Numerous techniques have been employed for studying the population biology and diversity of Phytophthora species, including RFLPs, random amplified polymorphic DNAs (RAPDs), amplified fragment length polymorphisms (AFLPs), microsatellites, single nucleotide polymorphisms (SNPs), and mitochondrial haplotype analyses.

RFLP analysis using Southern blots of digested genomic DNA probed with specific cloned nuclear DNA fragments has been useful for identification of subpopulations of several species $(86,98,183)$. RFLP analysis of purified mitochondrial DNA (mtDNA) in agarose gels also has been useful for identification of species as well as subpopulations (reviewed in Erwin and Ribeiro, 82), but is time-consuming due to the effort required for mtDNA purification. With the high copy number of mtDNA, digestion of total DNA with restriction enzymes that cut in GC-rich regions can sometimes be useful for generating discrete bands for differentiating isolates $(170,291)$. While these approaches for identification of species and subpopulations can be useful, the techniques described below are more suitable for this purpose.

RAPDs generate dominant markers that can provide a large number of polymorphic bands without having knowledge of genomic DNA sequences. It has been useful for analysis of $P$. capsici (139), P. cinnamomi (182), P. infestans (4), P. nicotianae (298), the relationship among Clade 1 species (60), P. colocasiae (206), and looking at genotypic diversity of several species in eastern India (233) and China (300). One main limitation of this marker system is the reproducibility of results between different labs and even between different thermalcyclers. One approach to alleviate this problem is to only use primers that generate robust bands, although a better approach is to generate sequence characterized amplified region (SCAR) markers by cloning the bands and designing primer pairs for their amplification (this also eliminates the need for using the same concentration of DNA for all samples as required for RAPD analysis).

AFLP analysis is another technique that generates dominant markers for population analysis where there is little knowledge of genomic DNA sequences. The technique can generate a large number of markers, is relatively straightforward, and is more transferable among labs than RAPDs. AFLP analysis has been used for comparison of isolates of $P$. andina (218), P. cactorum (26), $P$. capsici $(39,172)$, P. cinnamomi (73), P. drechsleri (171), P. infestans (4), P. nicotianae $(171,297)$, P. pinifolia (74), and $P$. ramorum (141). 
Simple sequence repeats (SSRs), generally referred to as microsatellites, are also commonly used in population analysis and assessment of intraspecific variation. This method is better to use than RAPDs or AFLPs due to the loci being codominant as well as having a higher degree of reproducibility among labs. The major drawback, however, is the need for genomic DNA sequence data to identify the location of potentially informative SSRs and design primers for their amplification. With a wider range of species undergoing genomic sequencing, data from more species should be available in the future. Another approach for generating the necessary sequence data without analyzing the entire genome is sequencing genome survey sequence libraries (5). SSR analysis has been successfully used with $P$. cinnamomi $(67,68), P$. infestans (175,292), $P$ alni (134), and $P$. ramorum (100,102,140,225, $226,280,281)$. When conducting population analyses, it is advisable to clone and sequence representative amplicons of each size class to ensure size differences are due to varying numbers of simple sequence repeats and not from length mutations in flanking regions. Stewart et al. (254) observed that capillary electrophoresis techniques were more accurate than gel electrophoresis for classifying SSR bands. Efforts to develop amplification primers for SSR loci for multiple species have been met with limited success $(90,175,237)$. A modification of this technique is called intersimple sequence repeat analysis and uses a single primer based on multiple copies of a simple sequence repeat (e.g., $\left.(\mathrm{CAT})_{6}\right)$; when this sequence is close enough on opposite strands of DNA, a band is amplified. This has been useful for population analysis of $P$. cactorum (110-112), P. citrophthora on citrus in Corsica (57) and Spain (8), as well as P. infestans (156).

Single nucleotide polymorphisms (SNPs) can also be used to study pathogen subpopulations as well as for development of diagnostic molecular markers for their detection. For example, Bilodeau et al. (30) identified two SNPs each in the $\beta$-tubulin and CBEL (cellulose binding elicitor lectin) genes that differentiated the North American from the European populations of P. ramorum (a primer extension assay for rapid identification of the genotypes was subsequently developed). A more comprehensive analysis of this approach was recently completed by Abbott et al. (3) for $P$. infestans using SNPs in the flanking regions of microsatellite loci. Nucleotide diversity averaged 1 SNP per $426 \mathrm{bp}$, and while heterozygosity precluded the use of many SNPs, a number of homozygous loci were identified that could be used for genotyping isolates. From examining a subset of unlinked loci, the authors concluded that 7 loci had a high probability of correct identification of genotypes (99.9\%). SNP analysis has also been useful in population studies with $P$. capsici $(94,95,127)$. In these latter studies, melt curve analysis rather than DNA sequencing was used to identify the SNPs. Mitochondrial loci can also be useful for identification of SNPs that differentiate subpopulations, but it must be kept in mind that in a sexually outcrossing population, the mitochondrial background would not reflect nuclear genotypic differences. SNPs in the coxl gene and coxl and cox 2 spacer region capable of differentiating the North American and European lineages of the clonally reproducing $P$. ramorum have been identified $(78,167,191)$.

Mitochondrial haplotypes identified using RFLP analysis have been useful for population studies of $P$. infestans (reviewed in 91,289 ), and the sequence data thus far suggest this method may be useful for differentiating haplotypes for a wide range of Phytophthora spp. Schena et al. (239) examined several mitochondrial regions they felt would be useful for finding interspecific polymorphisms in a wide range of species and with the trnY-rns spacer region observed intraspecific variation with a limited number of species where multiple isolates were examined. Using a comparative genomics approach with mitochondrial genome sequence data from NA-1 and EU-1 genotype $P$. ramorum isolates, sequences from 7 loci from a range of isolates identified 4 mitochondrial haplotypes among the 3 nuclear genotypes (191). More recent analysis of $P$. cinnamomi using 7 loci identified 45 mitochondrial haplotypes across 62 isolates (193), while there were 20 haplotypes for 51 isolates of $P$. nicotianae primarily from Italy (186). A multilocus analysis of the genus using four mitochondrial genes is currently in progress (Fig. 1); of the 64 species where multiple isolates had all four loci sequenced, $69 \%$ exhibited multiple mitochondrial haplotypes. Since these regions are predominantly coding regions rather than spacer regions, where many of the polymorphisms were identified in $P$. cinnamomi, it is likely that addition polymorphisms will be identified with further analysis. To facilitate this effort, the mitochondrial genomes of a number of Phytophthora species have been sequenced and comparative genomics employed to identify specific regions associated with genome rearrangements, as well as spacer regions that may be useful for haplotype classification (F. Martin, unpublished).

\section{Diagnostic Techniques}

Immunodetection. The enzyme-linked immunosorbent assay (ELISA) is a biochemical diagnostic tool based on antibodies that recognize an antigen specific to a plant pathogen. Commercially available ELISA tests for Phytophthora detection exist in a number of different formats, including assays for high throughput use in multi-well plates, and ImmunoStrips or Lateral Flow Devices (LFD) for single-use, on-site diagnostics. Immunodetection of Phytophthora in various types of plant related samples has been recently adopted by a broad range of plant professionals, mainly due to test availability, simplicity, efficiency, cost, and speed with which results are produced. Because the ImmunoStrip and LFD tests do not require special lab equipment, these formats are particularly suited for users with limited technical resources and experience.

ELISA-based assays typically utilize antibodies that detect a generic Phytophthora antigen and are not species specific $(6,184)$. The antibodies of some commercial ELISA tests are also known to react with some species of Pythium, yielding false-positive results. Numerous comparative studies involving the detection of Phytophthora using ELISA, plating, and/or PCR-based methods have highlighted differences between each test's performance, although the majority of samples testing positive by PCR and/or isolation have also tested positive by ELISA $(46,164,217,220)$. Since antigens can be present in tissues even after the pathogen is no longer viable, ELISA can be used for diagnostics even after certain treatments have been applied to control the disease, such as the application of fungicides or thermal inactivation.

ELISA-based protocols have successfully detected Phytophthora spp. in numerous types of samples, including plant foliage (173), plant roots $(22,184)$, soil $(244,262,294)$, irrigation water $(6,49,50)$, and hydroponic nutrient solutions (103). In certain cases, these assays have not detected the presence of the pathogen, yielding false-negative results. Failure to detect the antigens may be related to the type or quality of the host tissue and/or the particular Phytophthora species. For instance, some types of plant material may be difficult to macerate in order to release the antigens; one study reported a decrease in false-negative results by adding cutting, tearing, or grinding steps during sample preparation (173). In addition, the sensitivity of detection of different ELISA tests can vary in regard to the Phytophthora species, and even within isolates of the same species (6).

Species-specific antigens within the genus Phytophthora have yet to be identified, although more specific serological tests with higher sensitivity to particular Phytophthora species have been investigated (14). Antibodies with highest sensitivity and specificity to $P$. ramorum and $P$. kernoviae have been produced, although these antibodies were also found to be cross-reactive with other Phytophthora species. While species identification is not directly possible using ELISA-based assays, DNA on Phytophthora-positive ImmunoStrip and LFD nitrocellulose wicks can be amplified by adding a section of the membrane directly to an amplification reaction, such as loop mediated isothermal amplification (LAMP) or ITS amplification for sequence-based species identification. $P$. palmivora (272), $P$. ramorum, and $P$. kernoviae (265) have all been specifically detected in plant samples using this novel approach. 
ELISA-based assays are broadly adaptable. In certain cases, they have been utilized as a "prescreen" to reduce the number of samples needing further testing by more expensive and time-consuming diagnostic procedures for the confirmation of Phytophthora pathogens in large sample volume studies. In 2006, the USDAAPHIS approved a high throughput ELISA protocol as a primary screening tool for national $P$. ramorum surveys (46). The confirmation of $P$. ramorum within ELISA-positive samples is further required by PCR and/or culture plate isolation. ELISA procedures have also been utilized in multiple research studies to quantify the extent of Phytophthora infection $(103,244,262)$, as the intensity of color in a positive reaction is proportional to the amount of pathogen antigen within the original sample. Grote and Gabler (103) reported that ELISA was easier to perform and more selective than the most-probable number method for quantification of $P$. nicotianae when comparing treatments for controlling this pathogen in hydroponic tomato systems.

Molecular techniques for identification and detection. The development of the PCR technique for amplification of DNA has revolutionized molecular diagnostics and enabled highly specific pathogen detection from small amounts of plant tissue. With properly designed amplification primers, highly specific diagnostic assays can be developed using conventional PCR techniques. One drawback, however, is the need for running samples on an agarose gel to visualize the amplified band diagnostic of the pathogen in question, which can increase the time required for sample analysis, does not allow for quantification of target DNA, and is an impediment to high throughput sample processing. Greater sensitivity and rapid sample processing can be obtained with real-time PCR, where a dye included in the amplification mixture fluoresces in proportion to the amount of DNA template that has been amplified. This fluorescence is quantified by the thermal cycler during the amplification, thereby reducing the time needed to obtain results, but does increase the cost of equipment and supplies to run the assays. The ability to use 96 well plates also enables high throughput analysis of samples. There are several different chemistries used for real-time PCR. SYBR Green is a dye that fluoresces only when it has intercalated in double-stranded DNA, and melt curve analysis is then used to confirm if the appropriate target sequence has been amplified. Having highly specific primers and an amplification devoid of other nonspecific amplification products (including primer dimers) is essential for obtaining accurate results. In general, a greater level of specificity can be obtained using TaqMan probes, where a target specific oligonucleotide has a fluorochrome at one end and a quencher molecule at the other. When the probe anneals to the template and is incorporated into the doublestranded DNA, these molecules are separated and the dye fluoresces. There are also other technologies, such as Molecular Beacons and Scorpion primers, that work on a similar principle as the TaqMan assay where there is no fluorescence signal when the fluorochrome is in proximity to a quencher molecule. One advantage of Scorpion primers is that they can be run with shorter cycling times, thereby reducing the time needed for obtaining results (264). In general, these assays are more specific than SYBR Green due to the need for sequence identity in the labeled probes. In contrast to these technologies, with the Plexor Q-PCR system, one of the probes is labeled with a fluorochrome, and as the DNA is replicated a quencher molecule is brought into proximity, suppressing fluorescence, resulting in a decrease in fluorescence during template amplification. Another advantage of using technology that utilizes a fluorochrome and quencher combination compared to SYBR Green is the ability to multiplex diagnostic markers by using a different fluorochrome for each target, thereby allowing as many as five templates to be detected in a single amplification. However, with some combinations of primers and probes, there can be a reduction in the amplification efficiency of templates when multiplexed, so this needs to be evaluated prior to deploying the assay.

Loop mediated isothermal amplification (LAMP) (215) is another technique for amplification of pathogen template for diagnos- tic purposes. Four primers are designed to anneal to different regions of the target, and DNA polymerase with strand displacement capability is used to amplify the template when incubated at a constant temperature (reviewed at Eiken Chemical Company Genome site: http://loopamp.eiken.co.jp/e/index.html). Amplified product can be detected visually due to turbidity of the amplification mixture (magnesium pyrophosphate is generated as a byproduct of the amplification). Dyes that intercalate into the double-stranded DNA (ethidium bromide, PicoGreen, EvaGreen) can be added to the amplification and fluorescence quantified upon excitation with UV light or when run in a real-time PCR thermal cycler (264). One advantage of this technique is that expensive equipment is not required since the temperature is not cycled during the amplification process. A detection system based on this technology has been developed for $P$. ramorum, but the sensitivity of detection was less when compared to a standard ITS TaqMan assay (10 pg compared with $250 \mathrm{fg}$, respectively) and there was background detection of $P$. lateralis (264). A rapid diagnostic technique has been developed that utilizes a lateral flow device as a primary serological screen for the possible presence of a Phytophthora spp., with a piece of the nitrocellulose membrane containing pathogen DNA placed directly in a LAMP amplification mixture, thereby eliminating the need for DNA extraction (266).

Array technology. An alternative approach for identification of multiple pathogens or species that are present in a sample is the use of array technology (macro- or microarray). Highly conserved primers are used to amplify a diagnostic region from a wide range of organisms; this is labeled and then hybridized onto an array of species-specific oiligonucleotides. The particular positions where hybridization takes place identify which species are present in the sample. One big advantage of this technique is that the ability to include positive controls to ensure amplification of target sequences in the extracted DNA has occurred (for example, including genus or clade specific oligonucleotides) as well as including oligonucleotides from multiple loci and in duplicate positions on the array to confirm results. While this technique can be very effective for identifying which pathogens are present in a sample, it may not be amenable for high throughput analysis of multiple samples due to the need to use one array per sample and the cost associated with this (although the nitrocellulose membranes of macroarrays can be stripped and reused). In view of the broad range of species that can be included on the array, this technology does provide an interesting platform for community analysis as has been done with Pythium (176,259). For a review on the use of array technology for detection of pathogens, see Lievens and Thomma (179).

Lievens et al. (178) evaluated the position of base mismatches in oligonucleotides derived from ITS sequences of $P$. nicotianae used for spotting on the nitrocellulose membrane, whereas Anderson et al. (9) looked at melting kinetics of positive hybridizations to optimize species specificity for detection of a range of Phytophthora spp. and confirm if the pathogen was correctly identified. Zhang et al. (296) developed a macroarray for identification of fungal and oomycete pathogens of potato based on the ITS region of the rDNA that included a positive control for fungi and potato tissue as well as from two to five pathogen specific oligonucleotides for identification of several genera of pathogens (including P. capsici, P. erythroseptica, P. infestans, and P. nicotianae). A Phytophthora species-specific macroarray has been developed that utilizes species-specific oligonucleotides from the coxl gene, the spacer region between the coxl and $\operatorname{cox} 2$ genes, and the ITS region for genus and species-specific detection (W. Chen, Z. R. Djama, M. D. Coffey, F. N. Martin, G. Bilodeau, L. Radmer, G. Denton, and C. A. Lévesque, personal communication). While some cross reactivity was observed with the coxl oligonucleotides, the combination of all three loci allowed for correct identification of 82 out of 98 species tested (and 8 of 15 yet to be described species). Rather than using oligonuclotides as hybridization probes on the array membrane, Izzo and Mazzola (142) used the entire ITS region. While this reduced specificity (cross reactivity was observed for Pythium spp. that had less than 5 to $10 \%$ sequence divergence), it simplified 
array construction and allowed for the detection of a wider range of soil fungi. With the increased amount of sequence data available for Phytophthora and related genera, it is likely that arrays will be more available in the future.

Another approach to array technology for generating templates for real-time PCR is a technique called padlock probes (258). In this technique, an oligonucleotide is developed that consists of two universal primers, a unique sequence for the probe called a ZipCode sequence, and terminal sequences that are capable of annealing to adjacent complimentary sequences of the target organism. When the proper target sequence is present and the termini anneal, they are ligated together to circularize the probe, which allows the two universal primers to then amplify the circularized oligonucleotide. The unique ZipCode sequence is used to develop a probe for real-time PCR detection and quantification (279) or a hybridization oligonucleotide for an array (258). Using this approach, it is easier to develop multiplexed assays for a range of plant pathogens; Phytophthora genus-specific and several species-specific markers have been developed $(258,279)$. The use of 23 padlock probes specific for 22 Phytophthora spp. in a single microarray format was recently reported (36).

Massively parallel sequencing. On the forefront of diagnostics for a range of pathogens, including Phytophthora, is an approach known as massively parallel sequencing (MPS), which utilizes pyrosequencing (sometimes referred to as 454 sequencing). MPS is most commonly used to generate genomic sequences, but the tech- nology can be augmented to detect and genotype plant pathogens in an environmental sample (190,256). Because MPS generates very large numbers (millions) of overlapping short sequence reads for all DNA in a sample, these data contain both host and pathogen sequences. A sequence sample database (SSD) from representative pathogen isolates will need to be developed by identifying a minimum number of highly diagnostic sequences, also called "electronic probes" or "E-probes", that are conserved among each of the target strains or species. These sequences must not be found in the genomes of plants or other common plant endosymbionts (236). This technology is currently being examined for use in diagnostics for regulatory purposes (http://bioinfosu.okstate.edu/MPS_site/ people.html).

Other technologies. Tooley et al. (270) reported a ligase chain reaction for improving the specificity of detection of $P$. infestans using the ITS region of the rDNA. A thermal stable ligase was used to join two primers that annealed adjacent to each other on the target DNA, and the larger fragment is then visualized on a gel. By labeling the different primers with biotin or digoxigenin and using paramagnetic beads for separation, detection and quantification can be done by ELISA. A similar approach for detection and quantification of digoxigenin-labeled amplicons by ELISA was also used by Bailey et al. (15) for species-specific detection of several Phytophthora and Pythium spp.

Genus-specific diagnostic markers. While the ability to have a species-specific diagnostic marker is important, especially for a

Table 2. Selected references for species-specific diagnostic markers for detection of various Phytophthora spp. ${ }^{\text {a }}$

\begin{tabular}{|c|c|c|c|}
\hline Species & Assay type & Locus & Reference \\
\hline Phytophthora alni & Conventional & SCAR & Bakonyi et al. (16), De Merlier et al. (66), Ioos et al. (135) \\
\hline P. boehmeriae & Conventional & ITS & Shen et al. (248) \\
\hline \multirow[t]{3}{*}{ P. cactorum } & Conventional & SCAR & Causin et al. (52), Lilja et al. (181) \\
\hline & Conventional & ITS & Bhat and Browne (25), Boersma et al. (33), Lacourt et al. (168) \\
\hline & Real time & Ypt1 & Schena et al. (239) \\
\hline \multirow[t]{3}{*}{ P. cambivora } & Conventional & SCAR & Schubert et al. (245) \\
\hline & & ITS & Boersma et al. (33) \\
\hline & Real time & Ypt1 & Schena et al. (239) \\
\hline \multirow[t]{2}{*}{ P. capsici } & Conventional & ITS & Silvar et al. (250), Ristiano et al. (231), Zhang et al. (299) \\
\hline & Real time & ITS & Silvar et al. (249), Pavón et al. (224) \\
\hline \multirow{5}{*}{ P. cinnamomi } & Capture probe & Cina & Coelho et al. (56) \\
\hline & Conventional & ITS & Boersma et al. (33), Williams et al. (293) \\
\hline & & Lpv & Kong et al. (162) \\
\hline & & SCAR & O'Brien (216) \\
\hline & Real time & Ypt1 & Schena et al. (239) \\
\hline \multirow[t]{3}{*}{ P. citricola } & Conventional & ITS & Schuburt et al. (245) \\
\hline & Real time & ITS & Böhm et al. (34) \\
\hline & & Ypt1 & Schena et al. $(239,240)$ \\
\hline \multirow[t]{2}{*}{ P. citrophthora } & Conventional & SCAR & Ersek et al. (81), Goodwin et al. (97) \\
\hline & Real time & ITS & Ippolito et al. (137), Schena et al. (241) \\
\hline P. colocasiae & Conventional & ITS & Mishra et al. (207) \\
\hline \multirow[t]{3}{*}{ P. cryptogea } & Conventional & Ypt1 & Minerdi et al. (205) \\
\hline & & ITS & Boersma et al. (33) \\
\hline & Real time & Ypt1 & Schena et al. (239) \\
\hline \multirow[t]{3}{*}{ P. erythroseptica } & Conventional & ITS & Nanayakkara et al. (210), Tooley et al. (267) \\
\hline & Real time & ITS & Cullen et al. (63) \\
\hline & & $r p b 1$ & Atallah and Stevenson (13) \\
\hline P. europea & Real time & Ypt1 & Schena et al. (239) \\
\hline \multirow[t]{6}{*}{$P$. fragariae } & Conventional & ITS & Bonants et al. (35) \\
\hline & & ITS & Lacourt et al. (168) \\
\hline & & SCAR & Ioos et al. (135) \\
\hline & & ras & Ioos et al. (136) \\
\hline & & $\operatorname{trpl}$ & Ioos et al. (136) \\
\hline & Real time & ITS & Bonants et al. (38) \\
\hline P. fragariae rubi & Conventional & ITS & Schlenzig $(242,243)$ \\
\hline P. ilicis & Real time & Ypt1 & Schena et al. (239) \\
\hline \multirow{4}{*}{ P. infestans } & $\mathrm{LCR}^{\mathrm{b}}$ & ITS & Tooley et al. (270) \\
\hline & Conventional & ITS & Hussain et al. (129), Tooley et al. (267,269), Trout et al. (273) \\
\hline & & SCAR & Judelson and Tooley (146) \\
\hline & Real time & ras & Atallah and Stevenson (13) \\
\hline
\end{tabular}

\footnotetext{
${ }^{a}$ Validation of species specificity was conducted at varying levels among these citations; it is advisable to confirm specificity prior to their use.

${ }^{\mathrm{b}} \mathrm{LCR}=$ ligase chain reaction; LAMP = loop mediated isothermal amplification.

${ }^{c}$ When tested against 13 Pythium spp., 5 of them produced a positive reaction.
} 
regulated quarantine organism, from a broader perspective having a genus-specific marker capable of being multiplexed with a speciesspecific marker would enhance diagnostic capabilities by confirming if a Phytophthora spp. was responsible for the observed disease symptoms. A Phytophthora genus-specific diagnostic marker multiplexed with a species-specific marker was developed for conventional PCR based on the mitochondrially encoded coxl-2 spacer region (198). One advantage of this marker system is that this region has been sequenced for all described species and the data posted on publicly available websites (www.phytophthoradb.org, www.phytophthora-id.org), so amplicons generated from environmental samples can be sequenced and identified by BLAST analysis (if multiple species are present cloning will be required). Bilodeau et al. (29) developed a multiplexed TaqMan real-time PCR assay for $P$. ramorum that included a genus-specific marker based on the $\beta$-tubulin gene, although some cross reactivity with other oomycetes was observed. Other genus-specific diagnostic markers have been reported for singleplex detection of Phytophthora spp. The ras-related $Y p t-1$ gene has several conserved exons separated by variable introns that exhibit enough variation to be useful for development of Phytophthora genus- and speciesspecific diagnostic markers that did not cross amplify the Pythium spp. tested (239). Several genus-specific markers based on the ITS region have been reported as well; Drenth et al. (71) described a conventional PCR primer pair that amplified a 752-832 bp amplicon that could be used with RFLP analysis for species identification, while Kox et al. (164) reported a genus-specific TaqMan real-time PCR marker, although some Pythium spp. were also detected with this latter marker. Having a high copy target sequence like the ITS or mitochondrial DNA will improve the sensitivity of the assay over single copy targets like Yptl or $\beta$-tubulin. Even when using one of the higher copy regions, it may be necessary to do a nested amplification to visualize bands when doing conventional PCR with DNA extracted from plant tissue due to the low concentration of the pathogen relative to the plant DNA (198). In addition to genus-specific detection, diagnostic markers for amplification at a higher ordinal level have also been reported and may be useful as first round nested primers for detection from environmental samples (ITS [29,58]; 28S rRNA [12]; small rRNA subunit [23]; mitochondrially encoded cytochrome b region [93]).

Species-specific diagnostic markers. While random clones and cloned RAPD amplicons (Table 2) have been used for designing species-specific markers, a more efficient approach has been to sequence specific regions from a number of species and use unique regions to design species-specific primer pairs or TaqMan probes. Due to the large number of sequences available, this approach has historically focused on the ITS region, but more recent work has also looked at the ras-related protein Yptl $(238,239), \beta$-tubulin and elicitin $(29,31)$, and the spacer region between the mitochondrially encoded coxl and cox 2 genes (198,271). Multiplexing of assays developed from different loci improved the accuracy of results $(29,194)$. The ITS, elicitin gene family, and cox 1 and cox 2 spacer region are higher copy number and hence may provide greater sensitivity than single copy regions such as the Ypt1 and $\beta$-tubulin

Table 2. (continued from preceding page)

\begin{tabular}{|c|c|c|c|}
\hline Species & Assay type & Locus & Reference \\
\hline P. inundata & Real time & Ypt1 & Schena et al. (239) \\
\hline \multirow[t]{2}{*}{ P. kernoviae } & Real time & Ypt1 & Schena et al. $(239,240)$ \\
\hline & & ITS & Hughes et al. (125) \\
\hline \multirow[t]{2}{*}{ P. lateralis } & Conventional & ITS & Winton and Hansen (295) \\
\hline & Real time & Ypt1 & Schena et al. (239) \\
\hline P. medicaginis & Conventional & ITS & Liew et al. (180) \\
\hline P. megasperma & Real time & Ypt1 & Schena et al. (239) \\
\hline \multirow{2}{*}{ P. melonis } & Conventional & ITS & Wang et al. (284) \\
\hline & Real-time & ITS & Wang et al. (284) \\
\hline \multirow[t]{2}{*}{ P. nemorosa } & Real time & Ypt1 & Schena et al. (239) \\
\hline & Conventional & cox spacer & Martin et al. (198) \\
\hline \multirow[t]{6}{*}{ P. nicotianae } & Conventional & SCAR & Ersek et al. (81), Goodwin et al. (96) \\
\hline & & elicitin & Lacourt and Duncan (169) \\
\hline & & ITS & Boersma et al. (33), Grote et al. (104), Huang et al. (123), Tooley et al. (267) \\
\hline & & parAl & Kong et al. (160) \\
\hline & & Ypt1 & Meng and Wang (203) \\
\hline & Real time & ITS & Huang et al. (123), Ippolito et al. (137), Schena et al. (241) \\
\hline \multirow[t]{2}{*}{ P. pinifolia } & Conventional & ITS & Durán et al. (76) \\
\hline & Conventional & Ypt1 & Durán et al. (76) \\
\hline \multirow[t]{3}{*}{$P$. pseudosyringae } & Real time & Ypt1 & Schena et al. (239) \\
\hline & Conventional & cox spacer & Martin et al. (198) \\
\hline & Real-time & cox spacer & Tooley et al. (271) \\
\hline P. psychrophila & Real time & Ypt1 & Schena et al. (239) \\
\hline \multirow{2}{*}{ P. quercina } & Conventional & SCAR & Nechwatal et al. (211), Schubert et al. (245) \\
\hline & Real time & Ypt1 & Schena et al. $(239,240)$ \\
\hline \multirow[t]{12}{*}{ P. ramorum } & Conventional & ITS & Garbelotto et al. (89) \\
\hline & & cox spacer & Martin et al. (198) \\
\hline & & SCAR & Ioos et al. (135) \\
\hline & & gpal & Ioos et al. (136) \\
\hline & & trpl & Ioos et al. (136) \\
\hline & & $\operatorname{coxl}$ & Kroon et al. (167) \\
\hline & Real-time & ITS & Bilodeau et al. (31), Hayden et al. (114,115), Hughes et al. (126), Tomlinson et al. (264) \\
\hline & & cox spacer & Tooley et al. (271) \\
\hline & & Ypt1 & Schena et al. $(239,240)$ \\
\hline & & elicitin & Bilodeau et al. (31) \\
\hline & & $\beta$-tubulin & Bilodeau et al. (31) \\
\hline & $\mathrm{LAMP}^{\mathrm{b}}$ & ITS & Tomlinson et al. (264) \\
\hline P. sojae & Real-time & ITS & Bienapfl et al. (27), Wang et al. (285) \\
\hline Multiple spp. & PCR-ELISA & ITS & Bailey et al. (15) \\
\hline \multirow[t]{4}{*}{ Genus-specific } & Conventional & ITS & Drenth et al. (71) \\
\hline & Primers & cox spacer & Martin et al. (198) \\
\hline & Real time & ITS $^{\mathrm{c}}$ & Kox et al. (164) \\
\hline & & Ypt1 & Schena et al. (239) \\
\hline
\end{tabular}


markers. The sequence alignments of these regions used for designing the species-specific markers, as well as additional background information on their use, may be found in the diagnostic section of the Phytophthora Database (www.phytophthoradb.org). A listing of the species for which diagnostic markers have been developed is presented in Table 2. Recently, a new diagnostic marker system has been developed for pathogen detection at a genus- and species-specific level using a multiplexed approach with a single pair of amplification primers and multiple TaqMan probes (G. Bilodeau, F. N. Martin, and M. D. Coffey, unpublished). The amplification primers span a region of gene order differences between Phytophthora compared to plants and Pythium, thereby enhancing the specificity of detection. Species-specific probes that anneal to the genus-specific amplicon have been validated for 14 species, and sequence analysis for over 500 isolates representing most described species in the genus indicates this locus should provide a systematic approach for marker development for most species.

Important concepts to keep in mind when using molecular diagnostic techniques. With the development of rapid and sensitive techniques such as real-time PCR and the availability of sequence data for a number of loci, the ability to develop a sensitive species-specific marker system is becoming less of a challenge. There are, however, additional concepts to note while using molecular diagnostic markers.

DNA extraction. The level of sensitivity and specificity of any DNA-based diagnostic assay is only as good as the starting extraction. Good quality, amplifiable DNA free of PCR inhibitors must be extracted from the environmental sample for these techniques to work properly. Instead of using traditional chloroform/phenol DNA extraction techniques, most diagnostic labs currently use commercial DNA extraction kits due to their ease of use, potential for high throughput sample processing, and lack of a need for hazardous waste disposal. Depending on the kit and sample material being extracted, different quantities of PCR inhibitors may make it through the extraction process; trying to include too much sample in the extraction will enhance this problem. One approach to reduce this problem is to dilute the DNA to reduce the concentration of inhibitors; however, this also dilutes the target DNA and may lower the sensitivity of the diagnostic assay. Additional purification steps using polyvinylpyrrolidone $(164,174)$ or paramagnetic beads (28,164,177; P. Uribe and F. Martin, unpublished) have been used to improve the purity of the extracted DNA and thereby reduce the need for sample dilution. Bilodeau et al. (28) found that including an internal control in the amplification master mix significantly improved the ability to optimize the DNA extraction procedure from soil by providing a constant reference point for evaluating amplification efficiency.

Optimizing sensitivity of detection. As noted above, in addition to using DNA free of PCR inhibitors, selection of target sequences that are multiple copy is essential for obtaining a high level of diagnostic sensitivity. This is one advantage of the rDNA region, as it is present in much greater copy number than putative "single copy" genes such as $\beta$-tubulin. The selection of target sequences in other highly repetitive DNA can also increase the sensitivity of detection. Judelson and Tooley (146) obtained 100 times greater sensitivity targeting a highly repetitive element in $P$. infestans (14,000 copies per nucleus) compared to ITS detection. The mitochondrial DNA is also high in copy number relative to single copy nuclear genes. For TaqMan real-time PCR, the choice of master mixes can have an effect on sensitivity of detection; Bilodeau et al. (28) observed that for quantification of $V$. dahliae, the $C_{t}$ was reduced by approximately 4 rounds when Real Master Mix without Rox (5 Prime, Gaithersburg, MD) was used rather than TaqMan Universal PCR Master Mix (Applied Biosystems, Foster City, CA) for amplification of the same template DNA.

Multiplexing genus- and species-specific markers. While employing a species-specific diagnostic marker is essential for detecting the presence of a particular species, having the ability to determine if other Phytophthora spp. are present as well will enhance the information that can be obtained and perhaps identify new species. For example, including a genus-specific diagnostic marker in surveys of an ecosystem for a particular species will provide additional information on species communities, thereby allowing a broader view of the impact of Phytophthora. The availability of a sequence database for the amplified region broadly reflecting the genus will facilitate identification of what is present to a species level by BLAST analysis. If two species are present in a sample, cloning of the amplicon will be necessary in order to get clean sequence data.

Including positive or internal controls. To avoid false negatives due to the presence of PCR inhibitors preventing amplification, a positive control that will amplify in all samples should be multiplexed with the diagnostic marker. Target regions for these markers found in environmental samples that have been used include coxl gene for plants $(126,198,271)$, the $18 \mathrm{~S}$ rDNA region $(240,295)$, and RuBisCO (ribulose-1,5-bisphosphate carboxylase/oxygenase large subunit, 29). Judelson and Tooley (146) developed a positive control for their assay of $P$. infestans by cloning a band generated from $E$. coli by amplification with pathogen-specific primers at reduced stringency. In cases where pathogen quantification is desired, it is important to include an internal control so the presence of PCR inhibitors that may be reducing the amplification efficiency of the diagnostic marker (and hence increasing the $\mathrm{C}_{\mathrm{t}}$ ) can be identified. This can be done by adding a specific amount of internal control DNA to the amplification master mix and evaluating amplification compared to a water control amplification. Ideally, the amplification primers for the internal control would be the same as the pathogen diagnostic amplicon, but the TaqMan probe would be specific for the internal control. While this type of internal control has not been described for diagnostics of Phytophthora spp., it has for Phakopsora pachyrhizi (113) and Verticillium dahliae (28), and they should be amenable for modification for use with Phytophthora. When using positive and internal controls, it is important to determine if multiplexing reduces the amplification efficiency of the pathogen target amplicon.

Pathogen quantification. In addition to using an internal control in the assays used to quantify the amount of the pathogen, it is also important that the target sequence be present in a relatively constant amount among all isolates. While the ITS region of the rDNA has been the target sequence for a number of species-specific diagnostic assays, intraspecific differences in rDNA copy number have been reported for a range of Eumycotan fungi $(48,185,223$, $227,234)$. Although there is no direct evidence to confirm that this occurs in Phytophthora, there is indirect evidence suggesting that it does occur in the genus Pythium (192) and with Phytopythium vexans (252) and hence should be considered when designing quantification assays for Phytophthora. While rDNA copy number in isolates of Verticillium dahliae was recently reported to vary between approximately 24 and 73 copies depending on the isolate, the impact on the results of soil quantification was estimated to be a maximum difference of $1.8 \mathrm{C}_{\mathrm{t}}$; based on regression analysis between $\mathrm{C}_{\mathrm{t}}$ and soil plate counts of inoculum density $\left(R^{2}=0.96\right)$, this potential difference in copy number among isolates did not appear to influence the accuracy of results obtained for field soils collected from different regions of California (28).

Marker validation. Adequate validation of diagnostic markers is essential. This includes testing against isolates of the target pathogen collected from diverse regions to ensure a high degree of intraspecific conservation of annealing sites, evaluation of geographically diverse isolates of phylogenetically closely related species that have a higher degree of homology in annealing sites to ensure species specificity, a broad representation of species in the genus, and other microorganisms present in the samples that will be processed. At some point in this evaluation of specificity, DNA from the plants that will be assayed should be added to the master mix at a similar concentration to that used when assaying field samples to ensure there is no inhibition of target amplification (there have been examples where pathogen primers have annealed to host DNA [245]). Finally, marker validation should be done with envi- 
ronmental samples when culturing or DNA sequence analysis of amplicons has been done to confirm the presence of particular species.

Considerations when evaluating markers developed in another $l a b$. When first evaluating diagnostic markers reported in the literature, it is important to follow the amplification described procedure right down to the brand of Taq polymerase that was used. In the Martin lab we have noticed major differences in specificity and sensitivity of some TaqMan real-time PCR assays when the brand of master mix was changed from one company to another. This may also be possible when doing conventional PCR amplifications. Since thermal cyclers may be calibrated differently, we often run the initial amplification with an annealing temperature $2^{\circ} \mathrm{C}$ lower than recommended and then increase this to obtain specificity.

\section{Phytophthora Database}

In an effort to provide a comprehensive repository for information on the genus Phytophthora, a web portal called the Phytophthora Database (www.phytophthoradb.org) was developed (222). This database includes a listing of the species, their morphological features (for some species a listing of their hosts and pictures of diseased plants are presented), geographic distribution, and a listing of references about the genus. One important function of the project was to provide a comprehensive phylogenetic framework for the genus and tools that could be used for molecular identification. Eight nuclear and six mitochondrial loci have been sequenced for representative isolates of each species with the nuclear phylogeny published by Blair et al. (32) presented at the top of each species page. In the "Genetic Marker" section, there is a listing of primers and amplification conditions for all loci that have been sequenced. As of July 2011, a total of 6,192 sequences from 2,593 isolates representing 107 species were posted and are available for BLAST analysis for identification of unknown isolates. It is also possible to download the sequences as well as conduct some forms of analysis. Many of the cultures used to generate the sequence data came from the World Oomycete Genetic Resource Collection at the University of California, Riverside, and are available for other researchers to request. To reduce the need for obtaining permits for movement of pathogens, a bank of DNA extracted from a number of isolates has been established and can be obtained through the website (http://phytophthora.ucr.edu/ WPCcharges.htm). There is also a section on techniques for molecular identification and diagnostics that includes the sequence alignments used in the development of several genus- and species-specific marker systems to facilitate development of markers for additional species. While registration and log-in are not required to use the database, logged in users are able to store some of their analysis on the database server for future work. This website is a work in progress, and suggestions for improvement and contribution of content by the research community is encouraged.

\section{Future Directions of Research}

In the past decade, there have been significant advances in the molecular methods used for isolate identification, monitoring of populations, and species-specific detection. Several areas where further advancements would improve the capability of the research and regulatory community in these areas include:

- Having a comprehensive resource of information on the types (holotype, ex-holotype, neotype, and ex-neotype) would facilitate species identification as well as description of new species. Along these lines, work is in progress on completion of "Morphological/Molecular Identification Tools for Phytophthora based on the Types" that contains a Lucid Key, Tabular Key (expansion of Table 1), information on the types in different culture collections around the world (including the various accession numbers used for them), and datasheets all based on the morphological and molecular characters of the types and selected neotypes candidates (Z. G. Abad, Y. Balci, M. Coffey, and S. Kang, unpublished). It is also important to note the plasticity in morphological as well as physiological features when describing a novel species, which becomes evident only when a diverse set of isolates that represent the population is examined. Thus, novel species descriptions should include a variety of isolates to reduce confusion in species identification as well as DNA sequence data from a minimum of several loci to confirm uniqueness. In an effort to reduce confusion and make information on newly discovered species available to the research community, it also is important to finish formal species descriptions instead of relying on provisional species designations.

- Development of techniques that will reduce the need for specialized equipment or time that it takes to process a sample. The development of procedures where the nitrocellulose membrane from a serological detection kit is used as a source of DNA (eliminating the need for doing a DNA extraction procedure) and isothermal amplification is used for pathogen detection (265) is a step in the right direction. Additional testing is needed to see if this approach works for a wider range of host tissue and pathogen diagnostic markers. Another approach for isothermal amplification under commercial development (EnviroLogix, Portland, ME) is nicking enzyme amplification reaction (NEAR [251]). This approach utilizes enzymes capable of nicking double-stranded DNA at specific locations, a strand displacing DNA polymerase, and a set of primers with nicking enzyme binding sites in the $5^{\prime}$ end to conduct isothermal amplification. It has been reported to be influenced less by contaminants that make it through the DNA extraction procedures than PCR, and while it is currently being tested for detection of bacterial pathogens, it may also be useful for Phytophthora spp. While the "lab on a chip" described by Julich et al. (147) is technologically more complex than current techniques, it does provide a rapid (as short as 10 minutes) and sensitive means for detecting specific Phytophthora spp.

- Development of techniques to assess pathogen viability. While DNA from nonviable cells will degrade over time in the soil or plant tissue, the rate of degradation will vary depending on a number of factors, including environmental conditions. Having the ability to differentiate if the results of a diagnostic assay were from viable or nonviable pathogen cells would be helpful when making regulatory decisions. One technique for accomplishing this is to use an RNA template and reverse transcription prior to the PCR assay, an approach that has been used for $P$. cambivora (282) and P. ramorum (54) with cox1 or cox2 genes. Additional work in this area is needed to determine if this approach will work for other species as well.

- Improvement in approaches for determining cut-off values for positive results when running real-time PCR. This has been approached by using a $\mathrm{C}_{\mathrm{t}}$ value of 40 , determining at what value the regression analysis between pathogen concentration and $C_{t}$ is no longer linear, or determining the point where false positives are observed when a specific concentration of DNA from a related species is used. Ideally, the cut-off value would be determined by evaluating the presence or absence of the pathogen from a large dataset using multiple techniques to confirm results and be statistically supported using an approach similar to what was reported by Chandelier et al. (53) for a P. ramorum real-time PCR detection technique.

- Differentiating false positive results from valid positives. Differences in amplification kinetics between false positive and true positive amplifications can be observed in some real-time PCR diagnostic assays. Modeling a large enough sample size of these amplifications to identify specific characteristics of a false positive amplification may provide insight on additional techniques for improving the accuracy of pathogen detection. Sigmoidal curve fitting analysis has been used to model amplification kinetics to improve the accuracy of real time PCR quantification assays (235) and should be useful for this purpose as well.

- Development of primers specific for amplification of different genera or families of oomycetes that could be used in community analysis. As the results of Arcate et al. (12) suggested 
using an oomycete specific primer based on the 28S rDNA, there are likely to be oomycetes in the soil ecosystem that have yet to be described. Bent et al. (23) designed a straminipile specific primer pair from the $18 \mathrm{~S}$ region of the rDNA that will be useful for this purpose as well. Having a better selection of amplification primers to use would improve our ability to identify these and enhance our understanding of the diversity of oomycetes in the ecosystem. Knowing if there is variation in the copy number of the target sequences for different genera or species would be helpful for developing quantification assays.

- Our knowledge of diversity of the genus Phytophthora is largely based on observations when they were found in association with a plant disease; however, the widespread occurrence of diverse newly described Phytophthora species in forest ecosystems suggests that a broader ecosystems approach to analysis is needed. A systematic survey approach that includes stream, soil, and aboveground plant parts is needed to reveal the true diversity that exists within this genus and will help to fill in the taxonomic gaps. Furthermore, the biodiversity of Phytophthora spp. in natural ecosystems is largely based on temperate forests, leaving out the most diverse environment, the tropics. It is possible that some of the recent emerging temperate forest pathogens may have originated from increasingly disturbed tropical or subtropical environments.

- The ecological roles of many Phytophthora species remain enigmatic, particularly for species routinely found in streams. These appear to be part of the saprotrophic mycobiota similar to what has been observed for Halophytophthora, a sister genus commonly found in brackish water. A microbial approach that takes into account their functional roles in ecosystem health and their influence on plant diversity (by creating a negative feedback) may change our view on functional roles of this group of organisms.

\section{Conclusion}

The past decade has not only seen an approximate doubling in the number of described species within the genus Phytophthora, but a significant increase in the availability of DNA sequence data covering a variety of loci deposited in public databases. This has improved our ability to identify isolates to a species level as well as provided a phylogenetic framework for description of new species and better resolution of species complexes. Further collection of sequence data from geographically diverse isolates representing the range of variation within a species will provide the necessary data to delineate species boundaries and clarify the species concept in the genus. While this work is improving our ability to identify species based on phylogenetic grouping, it has also revealed that the genus has a much greater diversity than previously appreciated. With increased sampling of nonagricultural ecosystems, it is likely the list of new species will continue to grow, highlighting the need for a more thorough taxonomic evaluation of the genus that integrates both morphological and molecular criteria as well as a reevaluation of the ecological impact of this important genus.

The DNA sequences that have been collected for phylogenetic and identification purposes have also provided a resource that is useful for developing diagnostic assays. Genomic sequencing of several species and related genera should help in identifying additional loci that will be useful for designing hypervariable markers for population studies as well as loci that are stable on an intraspecific level that will be useful for developing species-specific diagnostic markers. While the development and widespread adoption of real-time PCR has revolutionized molecular diagnostics, the technology has not reached its full potential outside of a research setting due to factors such as cost of consumable supplies, the need to purchase specialized equipment, and the level of technical expertise needed to perform the assays. Further development of techniques for obtaining pathogen DNA amenable for high throughput processing that will provide clean template DNA, as well as developing assay techniques requiring less specialized equipment and technical expertise (such as isothermal amplification), will enhance our opportunities for a more widespread adoption of these technologies.

\section{Acknowledgments}

We thank Mike Benson, Cheryl Blomquist, Jaesoon Hwang, and Paul Tooley for their helpful comments during the preparation of this manuscript.

\section{Literature Cited}

1. Abad, Z. G. 2010. How to avoid misidentifying your isolates: the value of the morphological/phylogenetic key of Phytophthora extypes and neotypes. (Abstr.) Phytopathology 100:S150.

2. Abad, Z. G., Ivors, K. L., Gallup, C. A., Abad, J. A., and Shew, H. D. 2011. Morphological and molecular characterization of Phytophthora glovera sp. nov. from tobacco in Brazil. Mycologia 103:341-350.

3. Abbott, C. L., Gilmore, S. R., Lewis, C. T., Chapados, J. T., Peters, R. D. Platt, H. W., Coffey, M. D., and Lévesque, C. A. 2010. Development of a SNP genetic marker system based on variation in microsatellite flanking regions of Phytophthora infestans. Can. J. Plant Pathol. 32:440-457.

4. Abu-El Samen, F. M., Secor, G. A., and Gudmestad, N. C. 2003. Genetic variation among asexual progeny of Phytophthora infestans detected with RAPD and AFLP markers. Plant Pathol. 52:314-325.

5. Abubucker, S., Martin, J., Yin, Y., Fulton, L., Yang, S. P., HallsworthPepin, K., Johnston, J. S., Hawdon, J., McCarter, J. P., Wilson, R. K., and Mitreva, M. 2008. The canine hookworm genome: analysis and classification of Ancylostoma caninum survey sequences. Mol. Biochem. Parasitol. 157:187-192.

6. Ali-Shatayeh, M. S., MacDonald, J. D., and Kabashima, J. 1991. A method for using commercial ELISA tests to detect zoospores of Phytophthora and Pythium species in irrigation water. Plant Dis. 75:305311.

7. Ali-Shtayeh, M., Salah, A. A., and Jamous, R. M. 2003. Ecology of hymexazol-insensitive Pythium species in field soils. Mycopathologia 156:333-342.

8. Alvarez, L. A., León, M., Abad-Campos, P., García-Jiménez, J., and Vicent, A. 2011. Genetic variation and host specificity of Phytophthora citrophthora isolates causing branch cankers in Clementine trees in Spain. Eur. J. Plant Pathol. 129:103-117.

9. Anderson, N., Szemes, M., O'Brien, P., De Weerdt, M., Schoen, C., Boender, P., and Bonants, P. 2006. Use of hybridization melting kinetics for detecting Phytophthora species using three-dimensional microarrays: demonstration of a novel concept for the differentiation of detection targets. Mycol. Res. 110:664-671.

10. Ann, P. J., and Ko, W. H. 1980. Phytophthora insolita, a New Species from Taiwan. Mycologia 72:1180-1185.

11. Aragaki, M., and Uchida, J. Y. 2001. Morphological distinctions between Phytophthora capsici and P. tropicalis sp. nov. Mycologia 93:137-145.

12. Arcate, J. M., Karp, M. A., and Nelson, E. B. 2006. Diversity of Peronosporomycete (oomycete) communities associated with the rhizosphere of different plant species. Microb. Ecol. 51:36-50.

13. Atallah, Z. K., and Stevenson, W. R. 2006. A methodology to detect and quantify five pathogens causing potato tuber decay using real-time quantitative polymerase chain reaction. Phytopathology 96:1037-1045.

14. Avila, F. J., Schoedel, B., Abad, Z. G., Coffey, M. D., and Blomquist, C. 2010. ELISA and ImmunoStrip for detection of Phytophthora ramorum, $P$. kernoviae, and other Phytophthora species. Pages 378 in: Proc. Sudden Oak Death Fourth Sci. Symp. Gen. Tech. Rep. PSW-GTR-229. U. S. Dep. Agric. For. Serv. Pac. Southwest Res. Stn. Albany, CA.

15. Bailey, A. M., Mitchell, D. J., Manjunath, K. L., Nolasco, G., and Niblett, C. L. 2002. Identification to the species level of the plant pathogens Phytophthora and Pythium by using unique sequences of the ITS1 region of ribosomal DNA as capture probes for PCR ELISA. FEMS Microbiol. Lett. 207:153-158.

16. Bakonyi, J., Nagy, Z. Á., and Érsek, T. 2006. PCR-based DNA markers for identifying hybrids within Phytophthora alni. J. Phytopathol. 154:168177.

17. Bala, K., Robideau, G. P., Levesque, C. A., de Cock, A. W. A. M., Abad, G., Lodhi, A. M., Shahsad, S., Ghaffar, A., and Coffey, M. D. 2010 Phytopythium Abad, de Cock, Bala, Robideau, Lodhi \& Levesque, gen. nov. and Phytopythium sindhum Lodhi, Shahzad \& Levesque, sp. nov. Persoonia 24:136-137.

18. Balci, Y., Balci, S., Eggers, J., MacDonald, W. L., Juzwik, J., Long, R. P. and Gottschalk, K. W. 2007. Phytophthora spp. associated with forest soils in eastern and north-central U.S. oak ecosystems. Plant Dis. 91:705-710.

19. Balci, Y., and Halmschlager, E. 2003. Incidence of Phytophthora species in oak forests in Austria and their possible involvement in oak decline. For Pathol. 33:157-174.

20. Balcì, Y., and Halmschlager, E. 2003. Phytophthora species in oak ecosystems in Turkey and their association with declining oak trees. Plant 
Pathol. 52:694-702.

21. Beakes, G., and Sekimoto, S. 2009. The evolutionary phylogeny of Oomycetes-insights gained from studies of holocarpic parasites of algae and invertebrates. Pages 1-24 in: Oomycete Genetics and Genomics: Diversity, Interactions, and Research Tools. K. Lamour and S. Kamoun, eds. John Wiley and Sons, New York.

22. Benson, D. M. 1991. Detection of Phytophthora cinnamomi in azalea with commercial serological assay kits. Plant Dis. 75:478-482.

23. Bent, E., Loffredo, A., Yang, J. I., McKenry, M. V., Becker, J. O., and Borneman, J. 2009. Investigations into peach seedling stunting caused by a replant soil. FEMS Microbiol. Ecol. 68:192-200.

24. Bezuidenhout, C. M., Denman, S., Kirk, S. A., Botha, W. J., Mostert, L., and McLeod, A. 2010. Phytophthora taxa associated with cultivated Agathosma, with emphasis on the P. citricola complex and $P$. capensis $\mathrm{sp}$. nov. Persoonia: Mol. Phylogeny Evol. Fungi 25:32-49.

25. Bhat, R. G., and Browne, G. T. 2010. Specific detection of Phytophthora cactorum in diseased strawberry plants using nested polymerase chain reaction. Plant Pathol. 59:121-129.

26. Bhat, R. G., Colowit, P. M., Tai, T. H., Aradhya, M. K., and Browne, G. T. 2006. Genetic and pathogenic variation in Phytophthora cactorum affecting fruit and nut crops in California. Plant Dis. 90:161-169.

27. Bienapfl, J. C., Malvick, D. K., and Percich, J. A. 2011. Specific molecular detection of Phytophthora sojae using conventional and real-time PCR. Fungal Biol. 115:733-740.

28. Bilodeau, G., Koike, S. T., Uribe, P., and Martin, F. N. 2012. Development of an assay for rapid detection and quantification of Verticillium dahliae in soil. Phytopathology 102:331-343.

29. Bilodeau, G., Pelletier, G., Pelletier, F., Lévesque, C. A., and Hamelin, R. C. 2009. Multiplex real-time polymerase chain reaction (PCR) for detection of Phytophthora ramorum, the causal agent of sudden oak death. Can. J. Plant Pathol. 31:195-210.

30. Bilodeau, G. J., Lévesque, C. A., De Cock, A. W. A. M., Brière, S. C., and Hamelin, R. C. 2007. Differentiation of European and North American genotypes of Phytophthora ramorum by real-time polymerase chain reaction primer extension. Can. J. Plant Pathol. 29:408-420.

31. Bilodeau, G. J., Lévesque, C. A., De Cock, A. W. A. M., Duchaine, C., Brière, S., Uribe, P., Martin, F. N., and Hamelin, R. C. 2007. Molecular detection of Phytophthora ramorum by real-time polymerase chain reaction using TaqMan, SYBR Green, and molecular beacons. Phytopathology 97:632-642.

32. Blair, J. E., Coffey, M. D., Park, S. Y., Geiser, D. M., and Kang, S. 2008. A multi-locus phylogeny for Phytophthora utilizing markers derived from complete genome sequences. Fungal Genet. Biol. 45:266-277.

33. Boersma, J. G., Cooke, D. E. L., and Sivasithamparam, K. 2000. A survey of wildflower farms in the south-west of Western Australia for Phytophthora spp. associated with root rots. Aust. J. Exp. Agric. 40:10111019.

34. Böhm, J., Hahn, A., Schubert, R., Bahnweg, G., Adler, N., Nechwatal, J., Oehlmann, R., and Oßwald, W. 1999. Real-time quantitative PCR: DNA determination in isolated spores of the mycorrhizal fungus Glomus mosseae and monitoring of Phytophthora infestans and Phytophthora citricola in their respective host plants. J. Phytopathol. 147:409-416.

35. Bonants, P., Hagenaar-de Weerdt, M., Van Gent-Pelzer, M., Lacourt, I., Cooke, D., and Duncan, J. 1997. Detection and identification of Phytophthora fragariae Hickman by the polymerase chain reaction. Eur. J. Plant Pathol. 103:345-355.

36. Bonants, P. J. M., Gaszczyk, K., Mendes, O., Verstappen, E., and Schoen, C. D. 2011. Multiplex detection of Phytophthora: padlock probe based universal detection multiplex array (PUMA). (Abstr.) Phytopathology 101:S18.

37. Bonants, P. J. M., Hagenaar-De Weerdt, M., Man In 't Veld, W. A., and Baayen, R. P. 2000. Molecular characterization of natural hybrids of Phytophthora nicotianae and P. cactorum. Phytopathology 90:867-874.

38. Bonants, P. J. M., Van Gent-Pelzer, M. P. E., Hooftman, R., Cooke, D. E. L., Guy, D. C., and Duncan, J. M. 2004. A combination of baiting and different PCR formats, including measurement of real-time quantitative fluorescence, for the detection of Phytophthora fragariae in strawberry plants. Eur. J. Plant Pathol. 110:689-702.

39. Bowers, J. H., Martin, F. N., Tooley, P. W., and Luz, E. D. M. N. 2007. Genetic and morphological diversity of temperate and tropical isolates of Phytophthora capsici. Phytopathology 97:492-503.

40. Bowman, K. D., Albrecht, U., Graham, J. H., and Bright, D. B. 2007. Detection of Phytophthora nicotianae and P. palmivora in citrus roots using PCR-RFLP in comparison with other methods. Eur. J. Plant Pathol. 119:143-158.

41. Brasier, C. M. 2007. Pages 101-115 in: Phytophthora Biodiversity: How Many Phytopthora Species Are There? E. M. Goheen, and S. J. Frankel, eds. U. S. Dep. Agric. For. Serv. Pac. Southwest Res. Stn.

42. Brasier, C. M., Cooke, D. E. L., and Duncan, J. M. 1999. Origin of a new Phytophthora pathogen through interspecific hybridization. Proc. Natl. Acad. Sci. USA 96:5878-5883.

43. Brasier, C. M., Cooke, D. E. L., Duncan, J. M., and Hansen, E. M. 2003. Multiple new phenotypic taxa from trees and riparian ecosystems in Phytophthora gonapodyides-P. megasperma ITS Clade 6, which tend to be high-temperature tolerant and either inbreeding or sterile. Mycol. Res. 107:277-290.

44. Brasier, C. M., Kirk, S. A., Delcan, J., Cooke, D. E. L., Jung, T., and Man In 't Veld, W. A. 2004. Phytophthora alni sp. nov. and its variants: designation of emerging heteroploid hybrid pathogens spreading on Alnus trees. Mycol. Res. 108:1172-1184.

45. Buisman, C. J. 1927. Root rots caused by Phycomycetes. Diss. Utrecht $7: 1-51$.

46. Bulluck, R., Shiel, P., Berger, P., Kaplan, D., Parra, G., Li, W., Levy, L. Keller, J., Reddy, M. S., Sharma, N., Dennis, M., Stack, J., Pierzynski, J., O’Mara, J., Webb, C., Finley, L., Lamour, K., McKemy, J., and Palm, M. 2006. A comparative analysis of detection techniques used in US regulatory programs to determine presence of Phytophthora ramorum in Camellia japonica 'Nucio's Gem' in an infested nursery in Southern California. Plant Health Progress. Online publication. doi:101094/PHP2006-1016-01-RS

47. Burgess, T. I., Stukely, M. J. C., Jung, T., White, D., Hüberli, D., and Hardy, G. E. S. J. 2010. Molecular characterisation of a Phytophthora hybrid swarm in native ecosystems and waterways in Western Australia. In: 5th IUFRO Phytophthora Dis. For. Nat. Ecosyst. Auckland and Rotorua, New Zealand.

48. Butler, D. K., and Metzenberg, R. L. 1989. Premeiotic change of nucleolous organizer size in Neurospora. Genetics 122:783-791.

49. Cahill, D. M., and Hardham, A. R. 1994. Exploitation of zoospore taxis in the development of a novel dipstick immunoassay for the specific detection of Phytophthora cinnamomi. Phytopathology 84:193-200.

50. Cahill, D. M., and Hardham, A. R. 1994. A dipstick immunoassay for the specific detection of Phytophthora cinnamomi in soils. Phytopathology 84:1284-1292.

51. Camele, I., Marcone, C., and Cristinzio, G. 2005. Detection and identification of Phytophthora species in southern Italy by RFLP and sequence analysis of PCR-amplified nuclear ribosomal DNA. Eur. J. Plant Pathol. 113:1-14.

52. Causin, R., Scopel, C., Grendene, A., and Montecchio, L. 2005. An improved method for the detection of Phytophthora cactorum (L.C.) Schröeter in infected plant tissues using scar markers. J. Plant Pathol. 87:25-35.

53. Chandelier, A., Ivors, K., Garbelotto, M., Zini, J., Laurent, F., and Cavelier, M. 2006. Validation of a real-time PCR method for the detection of Phytophthora ramorum. EPPO Bull. 36:409-414.

54. Chimento, A., Cacciola, S. O., and Garbelotto, M. 2012. Detection of mRNA by reverse-transcription PCR as an indicator of viability in Phytophthora ramorum. For. Pathol. 42:14-21.

55. Cline, E. T., Farr, D. F., and Rossman, A. Y. 2008. A synopsis of Phytophthora with accurate scientific names, host range, and geographic distribution. Plant Health Progress. Online publication. doi:10.1094/PHP2008-0318-01-RS

56. Coelho, A. C., Cravador, A., Bollen, A., Ferraz, J. F. P., Moreira, A. C. Fauconnier, A., and Godfroid, E. 1997. Highly specific and sensitive nonradioactive molecular identification of Phytophthora cinnamomi. Mycol. Res. 101:1499-1507.

57. Cohen, S., Allasia, V., Venard, P., Notter, S., Vernière, C., and Panabières, F. 2003. Intraspecific variation in Phytophthora citrophthora from citrus trees in Eastern Corsica. Eur. J. Plant Pathol. 109:791-805.

58. Cooke, D. E. L., Drenth, A., Duncan, J. M., Wagels, G., and Brasier, C. M 2000. A molecular phylogeny of Phytophthora and related oomycetes. Fungal Genet. Biol. 30:17-32.

59. Cooke, D. E. L., Duncan, J. M., Williams, N. A., Hagenaar-De Weerdt, M., and Bonants, P. 2000. Identification of Phytophthora species on the basis of restriction enzyme fragment analysis of the internal transcribed spacer regions of the ribosomal RNA. EPPO Bull. 30:519-523.

60. Cooke, D. E. L., Kennedy, D. M., Guy, D. C., Russell, J., Unkles, S. E. and Duncan, J. M. 1996. Relatedness of Group I species of Phytophthora as assessed by randomly amplified polymorphic DNA (RAPDs) and sequences of ribosomal DNA. Mycol. Res. 100:297-303.

61. Cooke, D. E. L., Schena, L., and Cacciola, S. O. 2007. Tools to detect, identify and monitor Phytophthora species in natural ecosystems. J. Plant Pathol. 89:13-28.

62. Crandall, B. S. 1947. A new Phytophthora causing root and collar rot of Cinchona in Peru. Mycologia 39:218-223.

63. Cullen, D. W., Toth, I. K., Boonham, N., Walsh, K., Barker, I., and Lees, A. K. 2007. Development and validation of conventional and quantitative polymerase chain reaction assays for the detection of storage rot potato pathogens, Phytophthora erythroseptica, Pythium ultimum and Phoma foveata. J. Phytopathol. 155:309-315

64. Davison, E. M., and Tay, F. C. S. 2005. How many soil samples are needed to show that Phytophthora is absent from sites in the south-west of Western Australia? Aust. Plant Pathol. 34:293-297.

65. Delcán, J., and Brasier, C. M. 2001. Oospore viability and variation in zoospore and hyphal tip derivatives of the hybrid alder Phytophthoras. For. Pathol. 31:65-83.

66. De Merlier, D., Chandelier, A., Debruxelles, N., Noldus, M., Laurent, F. Dufays, E., Claessens, H., and Cavelier, M. 2005. Characterization of alder Phytophthora isolates from Wallonia and development of SCAR primers 
for their specific detection. J. Phytopathol. 153:99-107.

67. Dobrowolski, M. P., Tommerup, I. C., Blakeman, H. D., and O'Brien, P. A. 2002. Non-mendelian inheritance revealed in a genetic analysis of sexual progeny of Phytophthora cinnamomi with microsatellite markers. Fungal Genet. Biol. 35:197-212.

68. Dobrowolski, M. P., Tommerup, I. C., Shearer, B. L., and O'Brien, P. A. 2003. Three clonal lineages of Phytophthora cinnamomi in Australia revealed by microsatellites. Phytopathology 93:695-704.

69. Donahoo, R., Blomquist, C. L., Thomas, S. L., Moulton, J. K., Cooke, D. E. L., and Lamour, K. H. 2006. Phytophthora foliorum sp. nov., a new species causing leaf blight of azalea. Mycol. Res. 110:1309-1322.

70. Donahoo, R. S., and Lamour, K. H. 2008. Interspecific hybridization and apomixis between Phytophthora capsici and Phytophthora tropicalis. Mycologia 100:911-920.

71. Drenth, A., Wagels, G., Smith, B., Sendall, B., O'Dwyer, C., Irvine, G., and Irwin, J. A. G. 2006. Development of a DNA-based method for detection and identification of Phytophthora species. Aust. Plant Pathol. 35:147-159.

72. Druzhinina, I., Kopchinskiy, A. G., Komon, M., Bissett, J., Szakacs, G., and Kubicek, C. P. 2005. An oligonucleotide barcode for species identification in Trichoderma and Hypocrea Fungal Genet. Biol. 42:813828.

73. Duan, C. H., Riley, M. B., and Jeffers, S. N. 2008. Characterization of Phytophthora cinnamomi populations from ornamental plants in South Carolina, USA. Arch. Phytopathol. Plant Prot. 41:14-30.

74. Durán, A., Gryzenhout, M., Drenth, A., Slippers, B., Ahumada, R., Wingfield, B. D., and Wingfield, M. J. 2010. AFLP analysis reveals a clonal population of Phytophthora pinifolia in Chile. Fungal Biol. 114:746-752.

75. Durán, A., Gryzenhout, M., Slippers, B., Ahumada, R., Rotella, A., Flores, F., Wingfield, B. D., and Wingfield, M. J. 2008. Phytophthora pinifolia sp. nov. associated with a serious needle disease of Pinus radiata in Chile. Plant Pathol. 57:715-727.

76. Durán, A., Slippers, B., Gryzenhout, M., Ahumada, R., Drenth, A., Wingfield, B. D., and Wingfield, M. J. 2009. DNA-based method for rapid identification of the pine pathogen, Phytophthora pinifolia: Research letter. FEMS Microbiol. Lett. 298:99-104.

77. Elliott, C. G., and Math, V. B. 1983. Effect of 6-substituted sterols on sterol-induced reproduction in Phytophthora cactorum. Lipids 18:358-362.

78. Elliott, M., Sumampong, G., Varga, A., Shamoun, S. F., James, D., Masri, S., Brière, S. C., and Grünwald, N. J. 2009. PCR-RFLP markers identify three lineages of the North American and European populations of Phytophthora ramorum. For. Pathol. 39:266-278.

79. English, J. T., Laday, M., Bakonyi, J., Schoelz, J. E., and Érsek, T. 1999. Phenotypic and molecular characterization of species hybrids derived from induced fusion of zoospores of Phytophthora capsici and Phytophthora nicotianae. Mycol. Res. 103:1003-1008.

80. Érsek, T., and Ribeiro, O. 2010. Mini review article: an annotated list of new Phytophthora species described post 1996. Acta Phytopathol. Entomol. Hung. 45:251-266.

81. Ersek, T., Schoelz, J. E., and English, J. T. 1994. PCR amplification of species-specific DNA sequences can distinguish among Phytophthora species. Appl. Environ. Microbiol. 60:2616-2621.

82. Erwin, D. C., and Ribeiro, O. K. 1996. Phytophthora Diesases Worldwide. American Phytopathological Society, St. Paul, MN.

83. Ferguson, A. J., and Jeffers, S. N. 1999. Detecting multiple species of Phytophthora in container mixes from ornamental crop nurseries. Plant Dis. 83:1129-1136.

84. Fichtner, E. J., Lynch, S. C., and Rizzo, D. M. 2007. Detection, distribution, sporulation, and survival of Phytophthora ramorum in a California redwood-tanoak forest soil. Phytopathology 97:1366-1375.

85. Fichtner, E. J., Lynch, S. C., and Rizzo, D. M. 2009. Survival, Dispersal, and potential soil-mediated suppression of Phytophthora ramorum in a California redwood-tanoak forest. Phytopathology 99:608-619.

86. Förster, H., and Coffey, M. D. 1990. Mating behavior of Phytophthora parasitica: evidence for sexual recombination in oospores using DNA restriction fragment length polymorphisms as genetic markers. Exp. Mycol. 14:351-359.

87. Förster, H., Cummings, M. P., and Coffey, M. D. 2000. Phylogenetic relationships of Phytophthora species based on ribosomal ITS I DNA sequence analysis with emphasis on Waterhouse groups V and VI. Mycol. Res. 104:1055-1061

88. Gallegly, M., and Hong, C. 2008. Phytophthora. Identifying Species by Morphology and DNA Fingerprints. American Phytopathological Society, St. Paul, MN.

89. Garbelotto, M., Rizzo, D., Hayden, K., Meija-Chang, M., Davidson, J. M., and Tjosvold, S. A. 2002. Phytophthora ramorum and sudden oak death in California: III. Preliminary studies on pathogen genetics. Pages 765-774 in: U. S. Dep. Agric. For. Ser. Gen. Tech. PSW-GTR-184, 5th Sympos. Calif. Oak Woodlands. R. Sandiford, and D. McCreary, eds.

90. Garnica, D. P., Pinzón, A. M., Quesada-Ocampo, L. M., Bernal, A. J., Barreto, E., Grünwald, N. J., and Restrepo, S. 2006. Survey and analysis of microsatellites from transcript sequences in Phytophthora species: frequency, distribution, and potential as markers for the genus. BMC
Genomics 7. Online publication. doi:10.1186/1471-2164-7-245

91. Gavino, P. D., and Fry, W. E. 2002. Diversity in and evidence for selection on the mitochondrial genome of Phytophthora infestans. Mycologia 94:781-793.

92. Ghimire, S. R., Richardson, P. A., Moorman, G. W., Lea-Cox, J. D., Ross, D. S., and Hong, C. X. 2009. An in-situ baiting bioassay for detecting Phytophthora species in irrigation runoff containment basins. Plant Pathol. 58:577-583

93. Giresse, X., Ahmed, S., Richard-Cervera, S., and Delmotte, F. 2010 Development of new oomycete taxon-specific mitochondrial cytochrome b region primers for use in phylogenetic and phylogeographic studies. J. Phytopathol. 158:321-327.

94. Gobena, D., McGrath, M. T., and Lamour, K. Survival and spread of Phytophthora capsici on Long Island, New York. Mycol. Progress. In press.

95. Gobena, D., Roig, J., Galmarini, C. R., Hulvy, J., and Lamour, K. Genetic diversity of Phytophthora capsici isolates from pepper and pumpkin in Argentina. Mycologia. In press.

96. Goodwin, P. H., Kirkpatrick, B. C., and Duniway, J. M. 1989. Cloned DNA probes for identification of Phytophthora parasitica. Phytopathology 79:716-721

97. Goodwin, P. H., Kirkpatrick, B. C., and Duniway, J. M. 1990 Identification of Phytophthora citrophthora with cloned DNA probes. Appl. Environ. Microbiol. 56:669-674.

98. Goodwin, S. B., Drenth, A., and Fry, W. E. 1992. Cloning and genetic analyses of two highly polymorphic, moderately repetitive nuclear DNAs from Phytophthora infestans. Curr. Genet. 22:107-115.

99. Goodwin, S. B., and Fry, W. E. 1994. Genetic analyses of interspecific hybrids between Phytophthora infestans and Phytophthora mirabilis. Exp. Mycol. 18:20-32.

100. Gross, E. M., Carbone, I., and Grunwald, N. J. 2009. Ancient isolation and independent evolution of the three clonal lineages of the exotic sudden oak death pathogen Phytophthora ramorum. Mol. Ecol. 18:1161-1174.

101. Gross, E. M., Larsen, M., Vercauteren, A., Werres, S., Heungens, K., an Grünwald, N. J. 2011. Phytophthora ramorum in Canada: evidence for migration within North America and from Europe. Phytopathology 101:166-171.

102. Gross, E. M., Cardenas, M. C., Myers, K., Forbes, G. A., Fry, W. E., Restrepo, S., and Grunwald, N. J. 2011. The plant pathogen Phytophthora andina emerged via hybridization of an unknown Phytohthora species and the Irish potato famine pathogen, P. infestans. PLoS One 6:e24543.

103. Grote, D., and Gabler, J. 1999. Quantification of Phytophthora nicotianae in tomato plants. Z. Pflanzenkrankh. Pflanzenschutz 106:445-454.

104. Grote, D., Olmos, A., Kofoet, A., Tuset, J. J., Bertolini, E., and Cambra, M. 2002. Specific and sensitive detection of Phytophthora nicotianae by simple and nested-PCR. Eur. J. Plant Pathol. 108:197-207.

105. Grünwald, N. J., Martin, F. N., Larsen, M. M., Sullivan, C. M., Press, C. M., Coffey, M. D., Hansen, E. M., and Parke, J. L. 2011. PhytophthoraID.org: a sequence-based Phytophthora identification tool. Plant Dis. 95:337-342.

106. Gu, Y. H., and Ko, W. H. 2000. Segregation following interspecific transfer of isolated nuclei between Phytophthora parasitica and P. capsici. Can. J. Microbiol. 46:410-416.

107. Haas, B. J., Kamoun, S., Zody, M. C., Jiang, R. H. Y., Handsaker, R. E., Cano, L. M., Grabherr, M., Kodira, C. D., Raffaele, S., Torto-Alalibo, T., Bozkurt, T. O., Ah-Fong, A. M. V., Alvarado, L., Anderson, V. L., Armstrong, M. R., Avrova, A., Baxter, L., Beynon, J., Boevink, P. C. Bollmann, S. R., Bos, J. I. B., Bulone, V., Cai, G., Cakir, C., Carrington, J. C., Chawner, M., Conti, L., Costanzo, S., Ewan, R., Fahlgren, N., Fischbach, M. A., Fugelstad, J., Gilroy, E. M., Gnerre, S., Green, P. J., Grenville-Briggs, L. J., Griffith, J., Grünwald, N. J., Horn, K., Horner, N. R., Hu, C. H., Huitema, E., Jeong, D. H., Jones, A. M. E., Jones, J. D. G. Jones, R. W., Karlsson, E. K., Kunjeti, S. G., Lamour, K., Liu, Z., Ma, L., MacLean, D., Chibucos, M. C., McDonald, H., McWalters, J., Meijer, H. J. G., Morgan, W., Morris, P. F., Munro, C. A., O'Neill, K., OspinaGiraldo, M., Pinzón, A., Pritchard, L., Ramsahoye, B., Ren, Q., Restrepo, S., Roy, S., Sadanandom, A., Savidor, A., Schornack, S., Schwartz, D. C., Schumann, U. D., Schwessinger, B., Seyer, L., Sharpe, T., Silvar, C., Song, J., Studholme, D. J., Sykes, S., Thines, M., Van De Vondervoort, P. J. I., Phuntumart, V., Wawra, S., Weide, R., Win, J., Young, C., Zhou, S., Fry, W., Meyers, B. C., Van West, P., Ristaino, J., Govers, F., Birch, P. R. J., Whisson, S. C., Judelson, H. S., and Nusbaum, C. 2009. Genome sequence and analysis of the Irish potato famine pathogen Phytophthora infestans. Nature 461:393-398.

108. Hansen, E. M., Hamm, P. B., Julis, A. J., and Roth, L. F. 1979. Isolation, Incidence and Management of Phytophthora in Forest Tree Nurseries in the Pacific Northwest. Plant Dis. Rep. 63:607-611.

109. Hansen, E. M., Wilcox, W. F., Reeser, P. W., and Sutton, W. 2009. Phytophthora rosacearum and $P$. sansomeana, new species segregated from the Phytophthora megasperma "complex". Mycologia 101:129-135.

110. Hantula, J., Dusabenyagasani, M., and Hamelin, R. C. 1996. Random amplified microsatellites (RAMS) - a novel method for characterizing genetic variation within fungi. Eur. J. For. Pathol. 26:159-166.

111. Hantula, J., Lilja, A., Nuorteva, H., Parikka, P., and Werres, S. 2000. 
Pathogenicity, morphology and genetic variation of Phytophthora cactorum from strawberry, apple, rhododendron, and silver birch. Mycol. Res. 104:1062-1065.

112. Hantula, J., Lilja, A., and Parikka, P. 1997. Genetic variation and host specificity of Phytophthora cactorum isolated in Europe. Mycol. Res. 101:565-572.

113. Haudenshield, J. S., and Hartman, G. L. 2011. Exogenous control increase negative call veracity in multiplexed, quantitative PCR assays for Phakopsora pachyrhizi. Plant Dis. 95:343-352.

114. Hayden, K., Ivors, K., Wilkinson, C., and Garbelotto, M. 2006. TaqMan chemistry for Phytophthora ramorum detection and quantification, with a comparison of diagnostic methods. Phytopathology 96:846-854.

115. Hayden, K. J., Rizzo, D., Tse, J., and Garbelotto, M. 2004. Detection and quantification of Phytophthora ramorum from California forests using a real-time polymerase chain reaction assay. Phytopathology 94:1075-1083.

116. Hendrix, J. W. 1970. Sterols in growth and reproduction of fungi. Annu. Rev. Phytopathol. 8:111-130.

117. Hendrix, J. W., and Kuhlman, E. G. 1965. Factors affecting direct recovery of Phytophthora cinnamomi from soil. Phytopathology 55:1183-1187.

118. Ho, H. H. 1987. Effect of hymexazol on growth and reproduction of low temperature Phytophthora species. Mycopathologia 98:17-20.

119. Ho, H. H., and Chang, H. S. 1992. A re-evaluation of Phytophthora species described by K. Sawada in Taiwan. Mycotaxon 43:297-316.

120. Hong, C., Gallegly, M. E., Richardson, P. A., and Kong, P. 2011. Phytophthora pini Leonian resurrected to distinct species status. Mycologia 103:351-360.

121. Hong, C., Richardson, P. A., and Kong, P. 2002. Comparison of membrane filters as a tool for isolating pythiaceous species from irrigation water. Phytopathology 92:610-616.

122. Hong, C. X., Gallegly, M. E., Richardson, P. A., Kong, P., Moorman, G. W., Lea-Cox, J. D., and Ross, D. S. 2010. Phytophthora hydropathica, a new pathogen identified from irrigation water, Rhododendron catawbiense and Kalmia latifolia. Plant Pathol. 59:913-921.

123. Huang, J., Wu, J., Li, C., Xiao, C., and Wang, G. 2010. Detection of Phytophthora nicotianae in soil with real-time quantitative PCR. J. Phytopathol. 158:15-21.

124. Hüberli, D., Tommerup, I. C., and Hardy, G. E. S. J. 2000. False-negative isolations or absence of lesions may cause mis-diagnosis of diseased plants infected with Phytophthora cinnamomi. Aust. Plant Pathol. 29:164169.

125. Hughes, K. J. D., Tomlinson, J. A., Giltrap, P. M., Barton, V., Hobden, E., Boonham, N., and Lane, C. R. 2011. Development of a real-time PCR assay for detection of Phytophthora kernoviae and comparison of this method with a conventional culturing technique. Eur. J. Plant Pathol. 131:1223-1231.

126. Hughes, K. J. D., Tomlinson, J. A., Griffin, R. L., Boonham, N., Inman, A. J., and Lane, C. R. 2006. Development of a one-step real-time polymerase chain reaction assay for diagnosis of Phytophthora ramorum. Phytopathology 96:975-981.

127. Hulvey, J., Gobena, D., Finley, L., and Lamour, K. 2010. Co-occurrence and genotypic distribution of Phytophthora species recovered from watersheds and plant nurseries of eastern Tennessee. Mycologia 102:11271133 .

128. Hurtado-Gonzales, O. P., Aragon-Caballero, L. M., Flores-Torres, J. G., Man, W., and Lamour, K. H. 2009. Molecular comparison of natural hybrids of Phytophthora nicotianae and P. cactorum infecting loquat trees in Peru and Taiwan. Mycologia 101:496-502.

129. Hussain, S., Lees, A. K., Duncan, J. M., and Cooke, D. E. L. 2005. Development of a species-specific and sensitive detection assay for Phytophthora infestans and its application for monitoring of inoculum in tubers and soil. Plant Pathol. 54:373-382.

130. Hwang, J., Oak, S. W., and Jeffers, S. N. 2008. Detecting Phytophthora ramorum and other species of Phytophthora in streams in natural ecosystems using baiting and filtration methods. Pages 55-58 in: Proc. Sudden Oak Death 3rd Sci. Symp. Santa Rosa, CA.

131. Hwang, J., Oak, S. W., and Jeffers, S. N. 2011. Recovery of Phytophthora species from drainage points and tributaries within two forest stream networks: a preliminary report. N. Z. J. For. 41S:83-87.

132. Ilieva, E., Man In 't Veld, W. A., Veenbaas-Rijks, W., and Pieters, R. 1998. Phytophthora multivesiculata, a new species causing rot in Cymbidium. Eur. J. Plant Pathol. 104:677-684.

133. Ioos, R., Andrieux, A., Marcais, B., and Frey, P. 2007. New Hypothesis on the origin of the interspecific hybrid Oomycete Phytophthora alni. Pages 61-62 in: 4th Meeting of the IUFRO Working Party S07.02.09. E. M. Goheen, and S. J. Frankel, eds. USDA-FS PSW-GTR-221, Monterey, CA.

134. Ioos, R., Barrès, B., Andrieux, A., and Frey, P. 2007. Characterization of microsatellite markers in the interspecific hybrid Phytophthora alni ssp. alni, and cross-amplification with related taxa. Mol. Ecol. Notes 7:133137.

135. Ioos, R., Husson, C., Andrieux, A., and Frey, P. 2005. SCAR-based PCR primers to detect the hybrid pathogen Phytophthora alni and its subspecies causing alder disease in Europe. Eur. J. Plant Pathol. 112:323-335.

136. Ioos, R., Laugustin, L., Schenck, N., Rose, S., Husson, C., and Frey, P. 2006. Usefulness of single copy genes containing introns in Phytophthora for the development of detection tools for the regulated species $P$. ramorum and P. fragariae. Eur. J. Plant Pathol. 116:171-176.

137. Ippolito, A., Schena, L., Nigro, F., Soleti Ligorio, V., and Yaseen, T. 2004 Real-time detection of Phytophthora nicotianae and P. citrophthora in citrus roots and soil. Eur. J. Plant Pathol. 110:833-843.

138. Irwin, J. A. G. 1991. Phytophthora macrochlamydospora, a new species from Australia. Mycologia 83:517-519.

139. Islam, S. Z., Babadoost, M., Lambert, K. N., Ndeme, A., and Fouly, H. M. 2005. Characterization of Phytophthora capsici isolates from processing pumpkin in Illinois. Plant Dis. 89:191-197.

140. Ivors, K., Garbelotto, M., Vries, I. D. E., Ruyter-Spira, C., Hekkert, B. T., Rosenzweig, N., and Bonants, P. 2006. Microsatellite markers identify three lineages of Phytophthora ramorum in US nurseries, yet single lineages in US forest and European nursery populations. Mol. Ecol. 15:1493-1505.

141. Ivors, K. L., Hayden, K. J., Bonants, P. J. M., Rizzo, D. M., and Garbelotto, M. 2004. AFLP and phylogenetic analyses of North American and European populations of Phytophthora ramorum. Mycol. Res. 108:378-392.

142. Izzo, A. D., and Mazzola, M. 2009. Hybridization of an ITS-based macroarray with ITS community probes for characterization of complex communities of fungi and fungal-like protists. Mycol. Res. 113:802-812.

143. Jee, H. J., and Ko, W. H. 1997. Stimulation of sexual reproduction in Phytophthora cactorum and $P$. parasitica by fatty acids and related compounds. Mycol. Res. 101:1140-1144.

144. Jeffers, S. N., and Aldwinckle, H. S. 1987. Enhancing detection of Phytophthora cactorum in naturally infested soil. Phytopathology 77:1475-1482.

145. Jeffers, S. N., and Martin, S. B. 1986. Comparison of two media selective for Phytophthora and Pythium species. Plant Dis. 70:1038-1043.

146. Judelson, H. S., and Tooley, P. W. 2000. Enhanced polymerase chain reaction methods for detecting and quantifying Phytophthora infestans in plants. Phytopathology 90:1112-1119.

147. Julich, S., Riedel, M., Kielpinski, M., Urban, M., Kretschmer, R., Wagner, S., Fritzsche, W., Henkel, T., Möller, R., and Werres, S. 2011. Development of a lab-on-a-chip device for diagnosis of plant pathogens. Biosens. Bioelectron. 26:4070-4075.

148. Jung, T. 2009. Beech decline in Central Europe driven by the interaction between Phytophthora infections and climatic extremes. For. Pathol. 39:73-94.

149. Jung, T., and Blaschke, M. 2004. Phytophthora root and collar rot of alders in Bavaria: distribution, modes of spread and possible management strategies. Plant Pathol. 53:197-208.

150. Jung, T., Blaschke, H., and Obwald, W. 2000. Involvement of soilborne Phytophthora species in central European oak decline and the effect of site factors on the disease. Plant Pathol. 49:706-718.

151. Jung, T., and Burgess, T. I. 2009. Re-evaluation of Phytophthora citricola isolates from multiple woody hosts in Europe and North America reveals a new species, Phytophthora plurivora sp. nov. Persoonia 22:95-110.

152. Jung, T., Burgess, T. I., Huberli, D., and Hardy, G. E. S. J. 2011 Phytophthora fuliavis. Fungal Planet 87:147.

153. Jung, T., and Nechwatal, J. 2008. Phytophthora gallica sp. nov., a new species from rhizosphere soil of declining oak and reed stands in France and Germany. Mycol. Res. 112:1195-1205.

154. Jung, T., Stukely, M. J. C., Hardy, G. E. S. J., White, D., Paap, T., Dunstan, W. A., and Burgess, T. I. 2011. Multiple new Phytophthora species from ITS clade 6 associated with natural ecosystems in Australia: evolutionary and ecological implications. Persoonia 26:13-39.

155. Kang, S., Mansfield, M. A., Park, B., Geiser, D. M., Ivors, K. L., Coffey, M. D., Grunwald, N. J., Martin, F. N., Lévesque, C. A., and Blair, J. E. 2010. The promise and pitfalls of sequence-based identification of plantpathogenic fungi and oomycetes. Phytopathology 100:732-737.

156. Knapova, G., and Gisi, U. 2002. Phenotypic and genotypic structure of Phytophthora infestans populations on potato and tomato in France and Switzerland. Plant Pathol. 51:641-653.

157. Ko, W. H. 1978. Heterothallic Phytophthora: evidence for hormonal regulation of sexual reproduction. J. Gen. Microbiol. 107:15-18.

158. Ko, W. H. 1980. Hormonal regulation of sexual reproduction in Phytophthora. J. Gen. Microbiol. 116:459-463.

159. Ko, W. H. 1998. Chemical stimulation of sexual reproduction in Phytophthora and Pythium. Bot. Bull. Acad. Sin. 39:81-86.

160. Kong, P., Hong, C., Jeffers, S. N., and Richardson, P. A. 2003. A speciesspecific polymerase chain reaction assay for rapid detection of Phytophthora nicotianae in irrigation water. Phytopathology 93:822-831.

161. Kong, P., Hong, C., Richardson, P. A., and Gallegly, M. E. 2003. Singlestrand-conformation polymorphism of ribosomal DNA for rapid species differentiation in genus Phytophthora. Fungal Genet. Biol. 39:238-249.

162. Kong, P., Hong, C. X., and Richardson, P. A. 2003. Rapid detection of Phytophthora cinnamomi using PCR with primers derived from the Lpv putative storage protein genes. Plant Pathol. 52:681-693.

163. Kong, P., Richardson, P. A., and Hong, C. 2005. Direct colony PCR-SSCP for detection of multiple pythiaceous oomycetes in environmental samples. J. Microbiol. Methods 61:25-32.

164. Kox, L. F. F., Van Brouwershaven, I. R., Van De Vossenberg, B. T. L. H., 
Van Den Beld, H. E., Bonants, P. J. M., and De Gruyter, J. 2007. Diagnostic values and utility of immunological, morphological, and molecular methods for in planta detection of Phytophthora ramorum. Phytopathology 97:1119-1129.

165. Kroon, L. P. N. M., Bakker, F. T., Van Den Bosch, G. B. M., Bonants, P. J. M., and Flier, W. G. 2004. Phylogenetic analysis of Phytophthora species based on mitochondrial and nuclear DNA sequences. Fungal Genet. Biol. 41:766-782.

166. Kroon, L. P. N. M., Brouwer, H., de Cock, A. W. A. M., and Govers, F. 2012. The genus Phytophthora anno 2012. Phytopathology 102:348-364.

167. Kroon, L. P. N. M., Verstappen, E. C. P., Kox, L. F. F., Flier, W. G., and Bonants, P. J. M. 2004. A rapid diagnostic test to distinguish between American and European populations of Phytophthora ramorum. Phytopathology 94:613-620.

168. LaCourt, I., Bonants, P. J. M., Van Gent-Pelzer, M. P. E., Cooke, D. E. L., Hagnaar-De Weerdt, M., Surplus, L., and Duncan, J. M. 1997. The use of nested primers in the polymerase chain reaction for the detection of Phytophthora fragariae and P. cactorum in strawberry. Acta Hortic. 439:829-838

169. LaCourt, I., and Duncan, J. M. 1997. Specific detection of Phytophthora nicotianae using the polymerase chain reaction and primers based on the DNA sequence of its elicitin gene ParA1. Eur. J. Plant Pathol. 103:73-83.

170. LaCourt, I., Panabieres, F., Marais, A., Venard, P., and Ricci, P. 1994. Intraspecific polymorphism of Phytophthora parasitica revealed by analysis of mitochondrial DNA restriction fragment length polymorphism. Mycol. Res. 98:562-568.

171. Lamour, K. H., Daughtrey, M. L., Benson, D. M., Hwang, J., and Hausbeck, M. K. 2003. Etiology of Phytophthora drechsleri and $P$. nicotianae $(=P$. parasitica $)$ diseases affecting floriculture crops. Plant Dis. 87:854-858

172. Lamour, K. H., and Hausbeck, M. K. 2001. Investigating the spatiotemporal genetic structure of Phytophthora capsici in Michigan. Phytopathology 91:973-980.

173. Lane, C. R., Hobden, E., Walker, L., Barton, V. C., Inman, A. J., Hughes, K. J. D., Swan, H., Colyer, A., and Barker, I. 2007. Evaluation of a rapid diagnostic field test kit for identification of Phytophthora species, including $P$. ramorum and $P$. kernoviae at the point of inspection. Plant Pathol. 56:828-835.

174. Langrell, S. R. H., Morel, O., and Robin, C. 2011. Touchdown nested multiplex PCR detection of Phytophthora cinnamomi and P. cambivora from French and English chestnut grove soils. Fungal Biol. 115:672-682.

175. Lees, A. K., Wattier, R., Shaw, D. S., Sullivan, L., Williams, N. A., and Cooke, D. E. L. 2006. Novel microsatellite markers for the analysis of Phytophthora infestans populations. Plant Pathol. 55:311-319.

176. Lévesque, C. A., Harlton, C. E., and De Cock, A. W. A. M. 1998. Identification of some oomycetes by reverse dot blot hybridization. Phytopathology 88:213-222.

177. Li, M., Senda, M., Komatsu, T., Suga, H., and Kageyama, K. 2010. Development of real-time PCR technique for the estimation of population density of Pythium intermedium in forest soils. Microbiol. Res. 165:695705.

178. Lievens, B., Claes, L., Vanachter, A. C. R. C., Cammue, B. P. A., and Thomma, B. P. 2006. Detecting single nucleotide polymorphisms using DNA arrays for plant pathogen diagnosis. FEMS Microbiol. Lett. 255:129139.

179. Lievens, B., and Thomma, B. P. H. J. 2005. Recent developments in pathogen detection arrays: implications for fungal plant pathogens and use in practice. Phytopathology 95:1374-1380.

180. Liew, E. C. Y., Maclean, D. J., and Irwin, J. A. G. 1998. Specific PCR based detection of Phytophthora medicaginis using the intergenic spacer region of the ribosomal DNA. Mycol. Res. 102:73-80.

181. Lilja, A. T., Parikka, P. K., Pääskynkivi, E. A., Hantula, J. I., Vainio, E. J., Vartiamäki, H. A., Lemmetty, A. H., and Vestberg, M. V. 2006. Phytophthora cactorum and Colletotrichum acutatum: survival and detection. Agric. Conspec. Sci. 71:121-128.

182. Linde, C., Drenth, A., and Wingfield, M. J. 1999. Gene and genotypic diversity of Phytophthora cinnamomi in South Africa and Australia revealed by DNA polymorphisms. Eur. J. Plant Pathol. 105:667-680.

183. Linde, C., Kemp, G. H. J., and Wingfield, M. J. 1999. Variation in pathogenicity among South African isolates of Phytophthora cinnamomi. Eur. J. Plant Pathol. 105:231-239.

184. MacDonald, J. D., Stites, J., and Kabashima, J. 1990. Comparison of serological and culture plate methods for detecting species of Phytophthora, Pythium, and Rhizoctonia in ornamental plants. Plant Dis. 74:655-659.

185. Maleszka, R., and Clark-Walker, G. D. 1993. Yeasts have a four-fold variation in ribosomal DNA copy number. Yeast 9:53-58.

186. Mammella, M. A., Cacciola, S. O., Martin, F., and Schena, L. 2011. Genetic characterization of Phytophthora nicotianae by the analysis of polymorphic regions of the mitochondrial DNA. Fungal Biol. 115:432442.

187. Man In 't Veld, W. A., De Cock, A. W. A. M., and Summerbell, R. C. 2007. Natural hybrids of resident and introduced Phytophthora species proliferating on multiple new hosts. Eur. J. Plant Pathol. 117:25-33.
188. Man In 't Veld, W. A., Rosendahl, K. C. H. M., Brouwer, H., and de Cock, A. W. A. M. 2011. Phytophthora gemini sp. nov., a new species isolated from the halophilic plant Zostera marina in the Netherlands. Fungal Biol. 115:724-732.

189. Man In 't Veld, W. A., Veenbaas-Rijks, W. J., Ilieva, E., De Cock, A. W. A. M., Bonants, P. J. M., and Pieters, R. 1998. Natural hybrids of Phytophthora nicotianae and Phytophthora cactorum demonstrated by isozyme analysis and random amplified polymorphic DNA. Phytopathology 88:922-929.

190. Mardis, E. R. 2008. The impact of next-generatioin sequencing technology on genetics. Trends Genet. 24:133-141.

191. Martin, F. N. 2008. Mitochondrial haplotype determination in the oomycete plant pathogen Phytophthora ramorum. Curr. Genet. 54:23-34.

192. Martin, F. N. 2009. Pythium genetics. Pages 213-239 in: Oomycete Genetics and Genomics. K. L. a. S. Kamoun, ed. John Wiley and Sons, Hoboken, NJ.

193. Martin, F. N., and Coffey, M. D. 2012. Mitochondrial haplotype analysis for differentiation of isolates of Phytophthora cinnamomi. Phytopathology 102:229-239.

194. Martin, F. N., Coffey, M. D., Zeller, K., Hamelin, R. C., Tooley, P. Garbelotto, M., Hughes, K. J. D., Kubisiak, T., Bilodeau, G. J., Levy, L., Blomquist, C., and Berger, P. H. 2009. Evaluation of molecular markers for Phytophthora ramorum detection and identification: testing for specificity using a standardized library of isolates. Phytopathology 99:390403.

195. Martin, F. N., and Tooley, P. W. 2003. Phylogenetic relationships among Phytophthora species inferred from sequence analysis of mitochondrially encoded cytochrome oxidase I and II genes. Mycologia 95:269-284.

196. Martin, F. N., and Tooley, P. W. 2003. Phylogenetic relationships of Phytophthora ramorum, $P$. nemorosa and $P$. pseudosyringae, three species recovered from areas in California with sudden oak death. Mycol. Res. 107:1379-1391.

197. Martin, F. N., and Tooley, P. W. 2004. Identification of Phytophthora isolates to species level using restriction fragment length polymorphism analysis of a polymerase chain reaction-amplified region of mitochondrial DNA. Phytopathology 94:983-991.

198. Martin, F. N., Tooley, P. W., and Blomquist, C. 2004. Molecular detection of Phytophthora ramorum, the causal agent of sudden oak death in California, and two additional species commonly recovered from diseased plant material. Phytopathology 94:621-631.

199. May, K. J., Drenth, A., and Irwin, J. A. G. 2003. Interspecific hybrids between the homothallic Phytophthora sojae and Phytophthora vignae. Australas. Plant Pathol. 32:353-359.

200. Mchau, G. R., and Coffey, M. D. 1995. Evidence for the existence of two subpopulations in Phytophthora capsici and a redescription of the species. Mycol. Res. 99:89-102.

201. Mchau, G. R. A., and Coffey, M. D. 1994. An integrated study of morphological and isozyme patterns found within a worldwide collection of Phytophthora citrophthora and a redescription of the species. Mycol. Res. 98:1291-1299.

202. Meadows, I. M., Colburn, G. C., and Jeffers, S. N. 2011. Evaluation of a copper hydroxide-based algicide to eliminate propagules of Phytophthora spp. in naturally-infested streams in South Carolina, USA: a preliminary report. N. Z. J. For. Sci. 41:3-5

203. Meng, J., and Wang, Y. 2010. Rapid detection of Phytophthora nicotianae in infected tobacco tissues and soil samples based on its Ypt1 gene. J. Phytopathol. 158:1-7.

204. Mills, S. D., Forster, H., and Coffey, M. D. 1991. Taxonomic structure of Phytophthora cryptogea and $P$. drechsleri based on isozyme and mitochondrial DNA analysis. Mycol. Res. 95:31-48.

205. Minerdi, D., Moretti, M., Li, Y., Gaggero, L., Garibaldi, A., and Gullino, M. L. 2008. Conventional PCR and real time quantitative PCR detection of Phytophthora cryptogea on Gerbera jamesonii. Eur. J. Plant Pathol. 122:227-237.

206. Mishra, A. K., Jeeva, M. L., Vidyadharan, P., Misra, R. S., and Hegde, V. 2010. Rapid and sensitive detection of Phytophthora colocasiae associated with leaf blight of taro by species-specific polymerase chain reaction assay. Ann. Microbiol. 60:209-215.

207. Mishra, A. K., Sharma, K., and Misra, R. S. 2010. Isozyme and PCRbased genotyping of epidemic Phytophthora colocasiae associated with taro leaf blight. Arch. Phytopathol. Plant Prot. 43:1367-1380.

208. Mitchell, D. J., and Kannwischer-Mitchell, M. E. 1992. Phytophthora. Pages 31-38. in: Methods for Research on Soilborne Phytopathogenic Fungi L. E. Singleton, J. D. Mihail, and C. M. Riush, eds. American Phytopathological Society, St. Paul, MN.

209. Mostowfizadeh-Ghalamfarsa, R., Panabieres, F., Banihashemi, Z., and Cooke, D. E. L. 2010. Phylogenetic relationship of Phytophthora cryptogea Pethybr. \& Laff and P. drechsleri Tucker. Fungal Biol. 114:325339.

210. Nanayakkara, U. N., Singh, M., Al-Mughrabi, K. I., and Peters, R. D. 2009. Detection of Phytophthora erythroseptica in above-ground potato tissues, progeny tubers, stolons and crop debris using PCR techniques. Am. J. Potato Res. 86:239-245.

211. Nechwatal, J., and Oßwald, W. 2001. Comparative studies on the fine root 
status of healthy and declining spruce and beech trees in the Bavarian Alps and occurrence of Phytophthora and Pythium species. For. Pathol. 31:257273.

212. Nelson, S. C., and Abad, G. Z. 2010. Phytophthora morindae, a new species causing black flag disease on noni (Morinda citrifolia L) in Hawaii. Mycologia 102:122-134.

213. Newhook, F. J., Waterhouse, G. M., and Stamps, D. J. 1978. Tabular key to the species of Phytophthora de Bary. Mycol. Pap. 43.

214. Nirenberg, H. I., Gerlach, W. F., and Grafenhan, T. 2009. Phytophthora x pelgrandis, a new natural hybrid pathogenic to Pelargonium grandiflorum hort. Mycologia 101:220-231.

215. Notomi, T., Okayama, H., Masubuchi, H., Yonekawa, T., Watanabe, K., Amino, N., and Hase, T. 2000. Loop meadiated isothermal amplification of DNA. Nucleic Acids Res. 28:e63.

216. O'Brien, P. A. 2008. PCR primers for specific detection of Phytophthora cinnamomi. Aust. Plant Pathol. 37:69-71.

217. O'Brien, P. A., Williams, N., and Stj Hardy, G. E. 2009. Detecting Phytophthora. Crit. Rev. Microbiol. 35:169-181.

218. Oliva, R. F., Kroon, L. P. N. M., Chacón, G., Flier, W. G., Ristaino, J. B., and Forbes, G. A. 2010. Phytophthora andina sp. nov., a newly identified heterothallic pathogen of solanaceous hosts in the Andean highlands. Plant Pathol. 59:613-625.

219. Olson, H. A., Carbone, I., and Benson, D. M. 2011. Phylogenetic history of Phytophthora cryptogea and Phytophthora drechsleri isolates from floriculture crops in North Carolina greenhouses. Phytopathology 101:1373-1384.

220. Osterbauer, N., and Trippe, A. 2005. Comparing diagnostic protocols for Phytophthora ramorum in rhododendron leaves. Plant Health Progress. Online publication. doi:10.1094/PHP-2005-0314-01-HN

221. Oudemans, P., Forster, H., and Coffey, M. D. 1994. Evidence for distinct isozyme subgroups within Phytophthora citricola and close relationships with P.capsici and P.citrophthora. Mycol. Res. 98:189-199.

222. Park, J., Park, B., Blair, J. E., Geiser, D. M., Isard, S., Mansfield, M. A., Nikolaeva, E., Park, S. Y., Russo, J., Kim, S. H., Greene, M., Ivors, K. L., Balci, Y., Peiman, M., Coffey, M. D., Jung, K., Lee, Y. H., Rossman, A., Farr, D., Cline, E., Grünwald, N. J., Luster, D. G., Schrandt, S., Martin, F., Makalowska, I., and Kang, S. 2008. Phytophthora Database: a cyberinfrastructure supporting the identification and monitoring of Phytophthora Plant Dis. 92:966-972.

223. Pasero, P., and Marilly, M. 1993. Size variation rDNA clusters in the yeasts Saccharomyces cerevisiae and Saccharomyces pombe. Mol. Gen. Genet. 236:448-452.

224. Pavón, C. F., Babadoost, M., and Lambert, K. N. 2008. Quantification of Phytophthora capsici oospores in soil by sieving-centrifugation and realtime polymerase chain reaction. Plant Dis. 92:143-149.

225. Prospero, S., Black, J. A., and Winton, L. M. 2004. Isolation and characterization of microsatellite markers in Phytophthora ramorum, the causal agent of sudden oak death. Mol. Ecol. Notes 4:672-674.

226. Prospero, S., Hansen, E. M., Grünwald, N. J., and Winton, L. M. 2007. Population dynamics of the sudden oak death pathogen Phytophthora ramorum in Oregon from 2001 to 2004. Mol. Ecol. 16:2958-2973.

227. Pukkila, P. J., and Skrzynia, C. 1993. Frequent changes in the number of reiterated ribosomal RNA genes throughout the lifecycle of the basidiomycete Coprinus cinereus. Genetics 133:203-211.

228. Rea, A. J., Jung, T., Burgess, T. I., Stukely, M. J. C., and Hardy, G. E. S. J. 2010. Phytophthora elongata sp. nov., a novel pathogen from the Eucalyptus marginata forest of Western Australia. Australas. Plant Pathol. 39:477-491.

229. Reeser, P. W., Sutton, W., Hansen, E. M., Remigi, P., and Adams, G. C. 2011. Phytophthora species in forest streams in Oregon and Alaska. Mycologia 103:22-35

230. Ristaino, J. B. 2012. A lucid key to the common Phytophthora species. Plant Dis. 96:897-903.

231. Ristaino, J. B., Madritch, M., Trout, C. L., and Parra, G. 1998. PCR amplification of ribosomal DNA for species identification in the plant pathogen genus Phytophthora. Appl. Environ. Microbiol. 64:948-954.

232. Robideau, G. P., De Cock, A. W. A. M., Coffey, M. D., Voglmayr, H., Brouwer, H., Bala, K., Chitty, D. W., Desaulniers, N., Eggertson, Q. A., Gachon, C. M. M., Hu, C. H., Kupper, F. C., Rintoul, T. L., Sarhan, E., Verstappen, E. C. P., Zhang, Y., Bonants, P. J. M., Ristaino, J. B., and Andre Levesque, C. 2011. DNA barcoding of oomycetes with cytochrome c oxidase subunit I and internal transcribed spacer. Mol. Ecol. Res. 11:1002-1011.

233. Roy, S. G., Bhattacharyya, S., Mukherjee, S. K., and Khatua, D. C. 2009. Molecular identification of Phytophthora spp. affecting some economically important crops in eastern India through ITS-RFLP and sequencing of the ITS region. J. Phytopathol. 157:666-674.

234. Rustchenko-Bulgac, E. P., Curran, T., and Sherman, F. 1993. Variation in the number of ribosomal DNA subunits in morphological mutants and normal strains of Candida albicans and in normal strains of Saccharomyces cerevisiae. J. Bacteriol. 175:7189-7199.

235. Rutledge, R. G. 2004. Sigmodial curve-fitting redefines quantitative realtime PCR with the prospective of developing automated high-throughput applications. Nucleic Acids Res. 10.1093/nar/gnh177.
236. Satya, R. V., Zayaljevski, N., Kumar, K. R. R., and Reifman, J. 2008. A high-throughput pipline for designing microarray-based pathogen diagnostic assays. BMC Bioinform. 9:185.

237. Schena, L., Cardle, L., and Cooke, D. E. L. 2008. Use of genome sequence data in the design and testing of SSR markers for Phytophthora species. BMC Genomics 9. Online publication. doi:10.1186/1471-2164-9-620

238. Schena, L., and Cooke, D. E. L. 2006. Assessing the potential of regions of the nuclear and mitochondrial genome to develop a "molecular tool box" for the detection and characterization of Phytophthora species. J. Microbiol. Methods 67:70-85.

239. Schena, L., Duncan, J. M., and Cooke, D. E. L. 2008. Development and application of a PCR-based 'molecular tool box' for the identification of Phytophthora species damaging forests and natural ecosystems. Plant Pathol. 57:64-75.

240. Schena, L., Hughes, K. J. D., and Cooke, D. E. L. 2006. Detection and quantification of Phytophthora ramorum, $P$. kernoviae, $P$. citricola and $P$. quercina in symptomatic leaves by multiplex real-time PCR. Mol. Plant Pathol. 7:365-379.

241. Schena, L., Nigro, F., and Ippolito, A. 2004. Real-time PCR detection and quantification of soilborne fungal pathogens: the case of Rosellinia necatrix, Phytophthora nicotianae, P. citrophthora, and Verticillium dahliae. Phytopathol. Mediterr. 43:273-280.

242. Schlenzig, A. 2009. Identification of Phytophthora fragariae var. rubi by PCR. Methods Mol. Biol. (Clifton, N.J.) 508:161-169.

243. Schlenzig, A., Cooke, D. E. L., and Chard, J. M. 2005. Comparison of a baiting method and PCR for the detection of Phytophthora fragariae var. rubi in certified raspberry stocks. OEPP/EPPO Bull. 35:87-91.

244. Schmitthenner, A. F. 1990. Predicting yield loss from Phytophthora megasperma f. sp. glycinea in soybean with quantitative immunoassay of Phytophthora in soil. (Abstr.) Phytopathology 80:962.

245. Schubert, R., Bahnweg, G., Nechwatal, J., Jung, T., Cooke, D. E. L., Duncan, J. M., Müller-Starck, G., Langebartels, C., Sandermann Jr, H. and Oßwald, W. 1999. Detection and quantification of Phytophthora species which are associated with root-rot diseases in European deciduous forests by species-specific polymerase chain reaction. Eur. J. For. Pathol. 29:169-188.

246. Schwartzburg, K., Hartzog, H., Landry, C., Rogers, J., and RandallSchadel, B. 2009. Page 61 in: Phytophthora of Concern to the United States February 18, 2009. USDA-APHIS-PPQ-CPHST-PERAL, Raleigh, NC.

247. Scott, P. M., Burgess, T. I., Barber, P. A., Shearer, B. L., Stukely, M. J. C. Hardy, G. E. S. J., and Jung, T. 2009. Phytophthora multivora sp. nov., a new species recovered from declining Eucalyptus, Banksia, Agonis and other plant species in Western Australia. Persoonia 22:1-13.

248. Shen, G., Wang, Y. C., Zhang, W. L., and Zheng, X. B. 2005. Development of a PCR assay for the molecular detection of Phytophthora boehmeriae in infected cotton. J. Phytopathol. 153:291-296.

249. Silvar, C., Díaz, J., and Merino, F. 2005. Real-time polymerase chain reaction quantification of Phytophthora capsici in different pepper genotypes. Phytopathology 95:1423-1429.

250. Silvar, C., Duncan, J. M., Cooke, D. E. L., Williams, N. A., Díaz, J., and Merino, F. 2005. Development of specific PCR primers for identification and detection of Phytophthora capsici Leon. Eur. J. Plant Pathol. 112:4352.

251. Spenlinhaur, T. R., Judice, S., Lampton, P., Hardingham, J., Estock, M., Kovacs, S., Hoyos, G., McFadd, T. K., and Parker, B. O. 2011. The use of isothermal DNA amplification (NEAR) in plant disease diagnostics. (Abstr.) Phytopathology 101:S215.

252. Spies, C. F. J., Mazzola, M., and McLeod, A. 2011. Characterisation and detection of Pythium and Phytophthora species associated with grapevines in South Africa. Eur. J. Plant Pathol. 131:103-119.

253. Stamps, D. J., Waterhouse, G. M., Newhook, F. J., and Hall, G. S. 1990 Revised tabular key to the species of Phytophthora. Mycol. Pap. 162

254. Stewart, S., Wickramasinghe, D., Dorrance, A. E., and Robertson, A. E. 2011. Comparison of three microsatellite analysis methods for detecting genetic diversity in Phytophthora sojae (Stramenopila: Oomycete). Biotechnol. Lett. 33:2217-2223.

255. Streito, J. C., Jarnouen de Villartay, G., and Tabary, F. 2002. Methods for isolating the alder Phytophthora. For. Pathol. 32:193-196.

256. Sugiyama, A., Vivanco, J. M., Jayanty, S. S., and Manter, D. K. 2010. Pyrosequencing assessment of soil microbial communities in organic and conventional potato farms. Plant Dis. 94:1329-1335.

257. Sutton, W., Hansen, E. M., Reeser, P. W., and Kanaskie, A. 2009. Stream monitoring for detection of Phytophthora ramorum in oregon tanoak forests. Plant Dis. 93:1182-1186.

258. Szemes, M., Bonants, P., de Weerdt, M., Baner, J., Landegren, U., and Schoen, C. D. 2005. Diagnostic application of padlock probes-multiplex detection of plant pathogens using universal microarrays. Nucleic Acids Res. 10.1093/nar/gni069.

259. Tambong, J. T., de Cock, A. W. A. M., Tinker, N. A., and Levesque, C. A. 2006. Oligonucleotide array for identification and detection of Pythium species. Appl. Environ. Microbiol. 72:2691-2706.

260. Themann, K., Werres, S., Lüttmann, R., and Diener, H. A. 2002. Observations of Phytophthora spp. in water recirculation system in commercial hardy ornamental nursery stock. Eur. J. Plant Pathol. 
108:337-343.

261. Thines, M., Choi, Y. J., Kemen, E., Ploch, S., Holub, E. B., Shin, D. H., and Jones, J. D. G. 2009. A new species of Albugo parasitic to Arabidopsis thaliana reveals new evolutionary patterns in white blister rusts (Albuginaceae). Persoonia 22:23-128.

262. Timmer, L. W., Menge, J. A., Zitko, S. E., Pond, E., Miller, S. A., and Johnson, E. L. V. 1993. Comparison of ELISA techniques and standard isolation methods for Phytophthora detection in citrus orchards in Florida and California. Plant Dis. 77:791-796.

263. Tomlinson, J. A. 1952. Brown core root rot of Primula caused by Phytophthora primulae n.sp. . Trans. Br. Mycol. Soc. 35:221-235.

264. Tomlinson, J. A., Barker, I., and Boonham, N. 2007. Faster, simpler, morespecific methods for improved molecular detection of Phytophthora ramorum in the field. Appl. Environ. Microbiol. 73:4040-4047.

265. Tomlinson, J. A., Dickinson, M. J., and Boonham, N. 2010. Rapid detection of Phytophthora ramorum and P. kernoviae by two-minute DNA extraction followed by isothermal amplification and amplicon detection by generic lateral flow device. Phytopathology 100:143-149.

266. Tomlinson, J. A., Dickinson, M., Hobden, E., Robinson, S., Giltrap, P. M., and Boonham, N. 2010. A five-minute DNA extraction method for expedited detection of Phytophthora ramorum following prescreening using Phytophthora spp. lateral flow devices. J. Microbiol. Methods 81:116-120.

267. Tooley, P. W., Bunyard, B. A., Carras, M. M., and Hatziloukas, E. 1997. Development of PCR primers from internal transcribed spacer region 2 for detection of Phytophthora species infecting potatoes. Appl. Environ. Microbiol. 63:1467-1475.

268. Tooley, P. W., and Carras, M. M. 2011. Enhanced recovery of Phytophthora ramorum from soil following 30 days of storage at $4^{\circ} \mathrm{C}$. J. Phytopathol. 159:641-643.

269. Tooley, P. W., Carras, M. M., and Lambert, D. H. 1998. Application of a PCR-based test for detection of potato late blight and pink rot in tubers. Am. J. Potato Res. 75:187-194.
270. Tooley, P. W., Hatziloukas, E., Scott, D. L., and Carras, M. M. 2002. Use of ligase chain reaction for enhanced detection of Phytophthora infestans. Can. J. Plant Pathol. 24:294-301.

271. Tooley, P. W., Martin, F. N., Carras, M. M., and Frederick, R. D. 2006 Real-time fluorescent polymerase chain reaction detection of Phytophthora ramorum and Phytophthora pseudosyringae using mitochondrial gene regions. Phytopathology 96:336-345.

272. Torres, G. A., Sarria, G. A., Varon, F., Coffey, M. D., Elliott, M. L., and Martinez, G. 2010. First Report of Bud Rot Caused by Phytophthora palmivora on African Oil Palm in Colombia. Plant Dis. 94:1163.

273. Trout, C. L., Ristaino, J. B., Madritch, M., and Wangsomboondee, T. 1997. Rapid detection of Phytophthora infestans in late blight-infected potato and tomato using PCR. Plant Dis. 81:1042-1048.

274. Tsao, P. H. 1983. Factors affecting isolation and qantification of Phytophthora from soil. In: Phytophthora. Its Biology, Taxonomy, Ecology and Pathology. D. C. Erwin, S. Bartnicki-Garcia, and P. H. Tsao, eds. American Phytopathological Society, St Paul, MN.

275. Tsao, P. H. 1990. Why many Phytophthora root rots and crown rots of tree and horticultural crops remain undetected. OEPP/EPPO Bull. 20:11-17.

276. Tsao, P. H., and Guy, S. O. 1977. Inhibition of Mortierella and Pyhium in a Phytophthora-isolation Medium containing hymexazol. Phytopathology 67:769-801

277. Tucker, C. M., and Milbrath, J. A. 1942. Root rot of Chamaecyparis caused by a species of Phytophthora. Mycologia 34:94-103.

278. Tyler, B. M., Tripathy, S., Zhang, X., Dehal, P., Jiang, R. H. Y., Aerts, A., Arredondo, F. D., Baxter, L., Bensasson, D., Beynon, J. L., Chapman, J. Damasceno, C. M. B., Dorrance, A. E., Dou, D., Dickerman, A. W. Dubchak, I. L., Garbelotto, M., Gijzen, M., Gordon, S. G., Govers, F., Grunwald, N. J., Huang, W., Ivors, K. L., Jones, R. W., Kamoun, S., Krampis, K., Lamour, K. H., Lee, M. K., McDonald, W. H., Medina, M., Meijer, H. J. G., Nordberg, E. K., Maclean, D. J., Ospina-Giraldo, M. D., Morris, P. F., Phuntumart, V., Putnam, N. H., Rash, S., Rose, J. K. C., Sakihama, Y., Salamov, A. A., Savidor, A., Scheuring, C. F., Smith, B. M.,

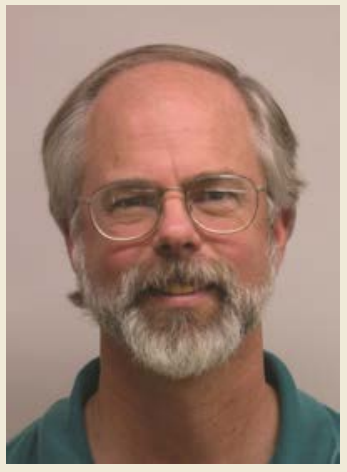

Frank N. Martin

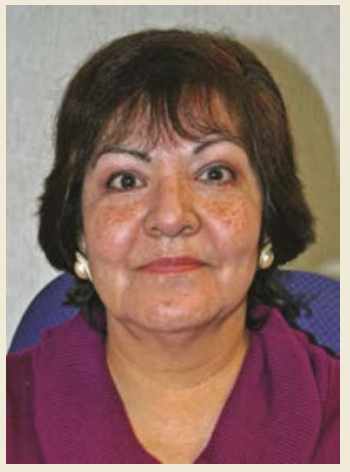

Z. Gloria Abad
Dr. Martin has been a Research Plant Pathologist with the USDA-ARS in Salinas, CA since 1996. He received his Ph.D. in plant pathology from the University of California, Berkeley, and was with the Plant Pathology Department at the University of Florida for 10 years prior to his current position. His research has focused on the ecology, biology, detection, identification, and phylogeny of the genera Pythium and Phytophthora.

Dr. Abad is a lead scientist at the USDA-APHIS-PPQCenter for Plant Health Science and Technology (CPHST) in Beltsville, MD, and adjunct assistant professor at Pennsylvania State University, Department of Plant Pathology. She received her M.Sc. at "La Molina" Agrarian University in Lima, Peru, in 1983 and her Ph.D. at North Carolina State University (NCSU) in 1993. Her research focuses primarily on the diagnostics of fungi and oomycetes of concern for the United States. Dr. Abad has worked actively on the taxonomy of oomycetes including Phytophthora, Pythium, and Phytopythium. She has been involved as chair, organizer, instructor, or invited speaker in a number of international symposiums and workshops on oomycetes.

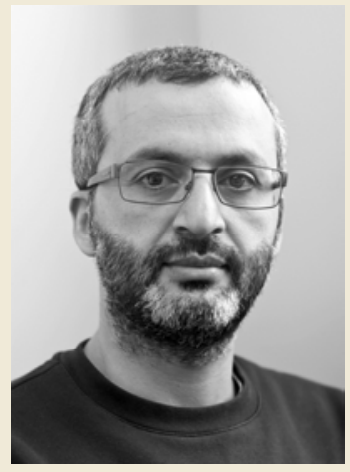

Yilmaz Balci

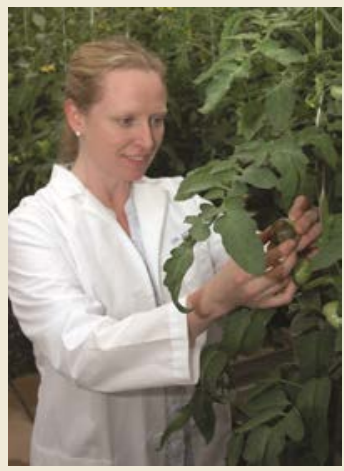

Kelly Ivors
Dr. Balci is an assistant professor of plant pathology in the Department of Plant Science and Landscape Architecture at the University of Maryland. He received his B.S. in forestry, M.Sc. in botany, and Ph.D. in forest pathology. He teaches introductory plant pathology and upper level course on diseases of woody plants. His research is focused on understanding the role Phytophthora play at ecosystem level and targets issues related to their taxonomy, biology, and ecology.

Dr. Ivors is an associate professor and extension specialist in the Department of Plant Pathology at North Carolina State University, and has worked at the Mountain Horticultural Crops Research and Extension Center outside of Asheville, NC, since 2004. Kelly received a B.S. and M.S. from Texas A\&M University, a Ph.D. from the Pennsylvania State University, and conducted postdoctoral research at University of California, Berkeley, on sudden oak death. She has statewide extension plant pathology responsibilities for vegetables, Christmas trees, and ornamental plants in North Carolina and collaborates with the NCSU Plant Disease and Insect Clinic on diagnoses and disease management recommendations. Her research and extension program focus on Phytophthora and other oomycete diseases. 
Sobral, B. W. S., Terry, A., Torto-Alalibo, T. A., Win, J., Xu, Z., Zhang, H., Grigoriev, I. V., Rokhsar, D. S., and Boore, J. L. 2006. Phytophthora genome sequences uncover evolutionary origins and mechanisms of pathogenesis. Science 313:1261-1266.

279. van Doorn, R., Szemes, M., Bonants, P., Kowalchuk, G. A., Salles, J. F., Ortenberg, E., and Schoen, C. 2007. Quantitative multiplex detection of plant pathogens using a novel ligation probe-based system coupled with universal, high-throughput real-time PCR on OpenArrays. BMC Genomics 10.1186/1471-2164-8-276

280. Vercauteren, A., De Dobbelaere, I., Grünwald, N. J., Bonants, P., Van Bockstaele, E., Maes, M., and Heungens, K. 2010. Clonal expansion of the Belgian Phytophthora ramorum populations based on new microsatellite markers. Mol. Ecol. 19:92-107.

281. Vercauteren, A., De Dobbelaere, I., Van Bockstaele, E., Maes, M., and Heungens, K. 2011. Genotypic and phenotypic characterization of the European A2 isolates of Phytophthora ramorum. Eur. J. Plant Pathol. 129:621-635.

282. Vettraino, A. M., Tomassini, A., and Vannini, A. 2009. Detection and quantification of mRNA by reverse transcription real time PCR as indicator of viability of Phytophthora cambivora in soil. Acta Hortic. 844:361-366

283. Villa, N. O., Kageyama, K., Asano, T., and Suga, H. 2006. Phylogenetic relationships of Pythium and Phytophthora species based on ITS rDNA, cytochrome oxidase II and beta-tubulin gene sequences. Mycologia 98:410-422.

284. Wang, Y., Ren, Z., and Zheng, X. 2007. Detection of Phytophthora melonis in samples of soil, water, and plant tissue with polymerase chain reaction. Can. J. Plant Pathol. 29:172-181.

285. Wang, Y., Zhang, W., and Zheng, X. 2006. Rapid and sensitive detection of Phytophthora sojae in soil and infected soybeans by species-specific polymerase chain reaction assays. Phytopathology 96:1315-1321.

286. Waterhouse, G. M. 1963. Key to the species of Phytophthora de Bary. Vol. Pap. 92. Commonw. Mycol. Inst. Kew, UK.

287. Waterhouse, G. M. 1970. The genus Phytophthora de Bary. Mycol Pap 122:1-59.

288. Waterhouse, G. M. 1974. Phytophthora japonica, a new name for Pythiomorpha oryzae. Trans. Br. Mycol. Soc. 63:419-420.

289. Wattier, R. A. M., Gathercole, L. L., Assinder, S. J., Gliddon, C. J., Deahl,
K. L., Shaw, D. S., and Mills, D. I. 2003. Sequence variation of intergenic mitochondrial DNA spacers (mtDNA-IGS) of Phytophthora infestans (Oomycetes) and related species. Mol. Ecol. Notes 3:136-138.

290. Weste, G., and Vithanage, K. 1978. Seasonal variation in numbers of chlamydospores in Victorian forest soils infected with Phytophthora cinnamomi. Aust. J. Bot. 26:657-662.

291. Whittaker, S. L., Assinder, S. J., and Shaw, D. S. 1994. Inheritance of mitochondrial DNA in Phytophthora infestans. Mycol. Res. 98:569-575.

292. Widmark, A. K., Andersson, B., Cassel-Lundhagen, A., Sandström, M. and Yuen, J. E. 2007. Phytophthora infestans in a single field in southwest Sweden early in spring: symptoms, spatial distribution and genotypic variation. Plant Pathol. 56:573-579.

293. Williams, N., Hardy, G. E. S. J., and O'Brien, P. A. 2009. Analysis of the distribution of Phytophthora cinnamomi in soil at a disease site in Western Australia using nested PCR. For. Pathol. 39:95-109.

294. Wilson, B. A., Aberton, J., and Cahill, D. M. 2000. Relationships between site factors and distribution of Phytophthora cinnamomi in the Eastern Otway Ranges, Victoria. Aust. J. Bot. 48:247-260.

295. Winton, L. M., and Hansen, E. M. 2001. Molecular diagnosis of Phytophthora lateralis in trees, water, and foliage baits using multiplex polymerase chain reaction. For. Pathol. 31:275-283.

296. Zhang, N., McCarthy, M. L., and Smart, C. D. 2008. A macroarray system for the detection of fungal and oomycete pathogens of solonaceous crops. Plant Dis. 92:953-960.

297. Zhang, X. G., Sun, W. X., Guo, L., Yu, J. F., and Chang, C. J. 2003. Genetic and pathogenic variation among tobacco black shank strains of Phytophthora parasitica var. nicotianae from the main tobacco growing in China. J. Phytopathol. 151:259-266.

298. Zhang, X. G., Zheng, G. S., Han, H. Y., Han, W., Shi, C. K., and Chang, C. J. 2001. RAPD PCR for diagnosis of Phytophthora parasitica var nicotianae isolates which cause black shank on tobacco. J. Phytopathol. 149:569-574.

299. Zhang, Z. G., Li, Y. Q., Fan, H., Wang, Y. C., and Zheng, X. B. 2006. Molecular detection of Phytophthora capsici in infected plant tissues, soil and water. Plant Pathol. 55:770-775.

300. Zheng, F. C., and Ward, E. 1998. Variation within and between Phytophthora species from rubber and citrus trees in China, determined by polymerase chain reaction using RAPDs. J. Phytopathol. 146:103-109. 